\title{
A Review of the Role of Imaging Modalities in the Evaluation of Viral Myocarditis with a Special Focus on COVID-19-Related Myocarditis
}

\author{
Adedayo Adeboye ${ }^{1,2}$, Deya Alkhatib ${ }^{1}$, , Asra Butt ${ }^{3}$, Neeraja Yedlapati ${ }^{1,4}$ and Nadish Garg ${ }^{5, *}$ \\ 1 Department of Cardiology, University of Tennessee Health Science Center, Memphis, TN 38163, USA; \\ aadeboye@uthsc.edu (A.A.); dalkhati@uthsc.edu (D.A.); nyedlapa@uthsc.edu (N.Y.) \\ 2 Department of Cardiology, Veterans Affairs Medical Center, Memphis, TN 38104, USA \\ 3 Department of Internal Medicine, University of Tennessee Health Science Center, Memphis, TN 38163, USA; \\ akhalid2@uthsc.edu \\ 4 Department of Cardiology, Methodist University Hospital, Memphis, TN 38104, USA \\ 5 Department of Cardiology, Memorial Hermann Southeast Hospital, Houston, TX 77089, USA \\ * Correspondence: ndgarg@gmail.com
}

check for

updates

Citation: Adeboye, A.; Alkhatib, D.; Butt, A.; Yedlapati, N.; Garg, N. A Review of the Role of Imaging Modalities in the Evaluation of Viral Myocarditis with a Special Focus on COVID-19-Related Myocarditis.

Diagnostics 2022, 12, 549.

https://doi.org/10.3390/

diagnostics12020549

Academic Editor: Sophie Mavrogeni

Received: 31 December 2021

Accepted: 6 February 2022

Published: 21 February 2022

Publisher's Note: MDPI stays neutral with regard to jurisdictional claims in published maps and institutional affiliations.

Copyright: () 2022 by the authors. Licensee MDPI, Basel, Switzerland. This article is an open access article distributed under the terms and conditions of the Creative Commons Attribution (CC BY) license (https:// creativecommons.org/licenses/by/ $4.0 /)$.

\begin{abstract}
Viral myocarditis is inflammation of the myocardium secondary to viral infection. The clinical presentation of viral myocarditis is very heterogeneous and can range from nonspecific symptoms of malaise and fatigue in subclinical disease to a more florid presentation, such as acute cardiogenic shock and sudden cardiac death in severe cases. The accurate and prompt diagnosis of viral myocarditis is very challenging. Endomyocardial biopsy is considered to be the gold standard test to confirm viral myocarditis; however, it is an invasive procedure, and the sensitivity is low when myocardial involvement is focal. Cardiac imaging hence plays an essential role in the noninvasive evaluation of viral myocarditis. The current coronavirus disease 2019 (COVID-19) pandemic has generated considerable interest in the use of imaging in the early detection of severe acute respiratory syndrome coronavirus 2 (SARS-CoV-2)-related myocarditis. This article reviews the role of various cardiac imaging modalities used in the diagnosis and assessment of viral myocarditis, including COVID-19-related myocarditis.
\end{abstract}

Keywords: viral myocarditis; COVID-19-related myocarditis; echocardiography; cardiac magnetic resonance imaging (CMR); cardiac CT; PET-CT; SPECT

\section{Introduction}

Myocarditis is a disease characterized by inflammation of the myocardial tissue, and it can be either infectious or non-infectious in etiology. Infectious causes include viruses, bacteria, fungi, and protozoa, with viruses being the leading cause of infectious myocarditis [1]. Viral myocarditis is seen in all age groups; however, neonates, children, and immunocompromised individuals are more commonly affected. The clinical presentation of viral myocarditis is heterogeneous and can be acute, subacute, or chronic in nature. The clinical features are nonspecific, with patients presenting with fatigue in subclinical disease to more fulminant disease associated with respiratory failure from acute decompensated heart failure, cardiogenic shock, arrhythmia, and sudden cardiac death in severe or fulminant cases. Occasionally, the pericardium can be involved, leading to myo-pericarditis with patients presenting with pleurisy and pericardial effusion [2].

The incidence of viral myocarditis is not exactly known, which is likely due to the challenges in confirming the diagnosis of viral myocarditis, as the recognized confirmatory test, endomyocardial biopsy (EMB), is infrequently obtained, and there is no noninvasive "gold standard" test. Moreover, the sensitivity of EMB is low and may be falsely negative, especially if myocarditis is focal [3,4]. Many viruses have been documented as causing 
myocarditis. The most common viral pathogens include coxsackieviruses, parvovirus B19, influenza virus, and, recently, coronaviruses [5].

Overall, an accurate diagnosis of viral myocarditis is dependent on a careful history and physical examination, cardiac biomarkers, electrocardiogram (ECG), and especially noninvasive cardiac imaging [6].

The current coronavirus disease 2019 (COVID-19) pandemic has shown that, in addition to respiratory involvement in the form of acute respiratory distress syndrome (ARDS), the heart can also be affected. Cardiac complications from COVID-19 include acute coronary syndrome (ACS), heart failure, cardiogenic shock, arrhythmias, and myocarditis. Myocarditis after coronavirus infection appears to be the most common cardiac complication, with about $7 \%$ mortality [7].

Early diagnosis with noninvasive cardiac imaging and aggressive and prompt treatment can help reduce cardiovascular morbidity and mortality related to COVID-19 infection $[8,9]$. This review article discusses the role, advantages, limitations, and evidence of various cardiac imaging techniques and modalities in the diagnosis and workup of viral myocarditis, with special focus on COVID-19-related myocarditis.

\section{Role of Imaging Modalities in Myocarditis}

\subsection{Echocardiography}

Transthoracic echocardiography (TTE) is a safe, widely available, and clinically extremely useful cardiac imaging tool, particularly for the initial assessment of viral myocarditis. The American College of Cardiology (ACC), American Heart Association (AHA), and European Society of Cardiology (ESC) Working Group on Myocardial and Pericardial Diseases recommend that all patients with clinically suspected myocarditis should undergo a TTE at initial presentation [10-14]. Poor acoustic windows in patients with obesity or chronic lung diseases is a well-known limitation of echocardiogram and can lead to an inadequate assessment of cardiac function and structure [15]. In general, echocardiographic features of acute myocarditis are subtle, with focal wall motion abnormalities and mildly reduced ejection fraction [16].

Advanced echocardiographic tools, such as three-dimensional (3D) imaging, speckle tracking, contrast echocardiography, and tissue Doppler imaging, can detect subtle abnormalities in ventricular function that can provide clues for the diagnosis of viral myocarditis [17].

\subsubsection{Two-Dimensional Transthoracic Echocardiography}

Acute viral myocarditis is usually associated with echocardiographic findings of left, right, or biventricular systolic and diastolic dysfunction. Viral infection of the myocardium leads to the infiltration of acute inflammatory cells in myocardial tissue, resulting in interstitial edema with a thickening of the ventricular wall, increased left ventricular (LV) mass index, and reduced ventricular contractility (refer to Figure 1) [18-20]. Usually, right ventricular (RV) dysfunction is accompanied by LV dysfunction. RV dysfunction is associated with increased morbidity and mortality and the need for heart transplantation. Pinamonti et al. reviewed echocardiographic studies of 42 patients with biopsy-proven myocarditis. In this study, a total of $23 \%$ of the patients had evidence of RV dysfunction, and the presence of RV dysfunction was associated with a worse prognosis [19]. Myocarditis may cause segmental or global dilatation of the LV, focal thickening of the ventricular wall, regional wall motion abnormalities, pericardial effusion, and focal interstitial edema of the myocardium (refer to Table 1). In several cases of acute myocarditis confirmed by biopsy, TTE was reported to be normal, especially in mild cases [20]. The likely explanation for a normal TTE is that either mild myocarditis does not significantly impact the left ventricular function or the changes in the left ventricular function are too subtle to be detected by 2 Dimensional (2D) echocardiography. In addition, echocardiographic findings cannot differentiate viral myocarditis from other forms of cardiomyopathy [16]. 


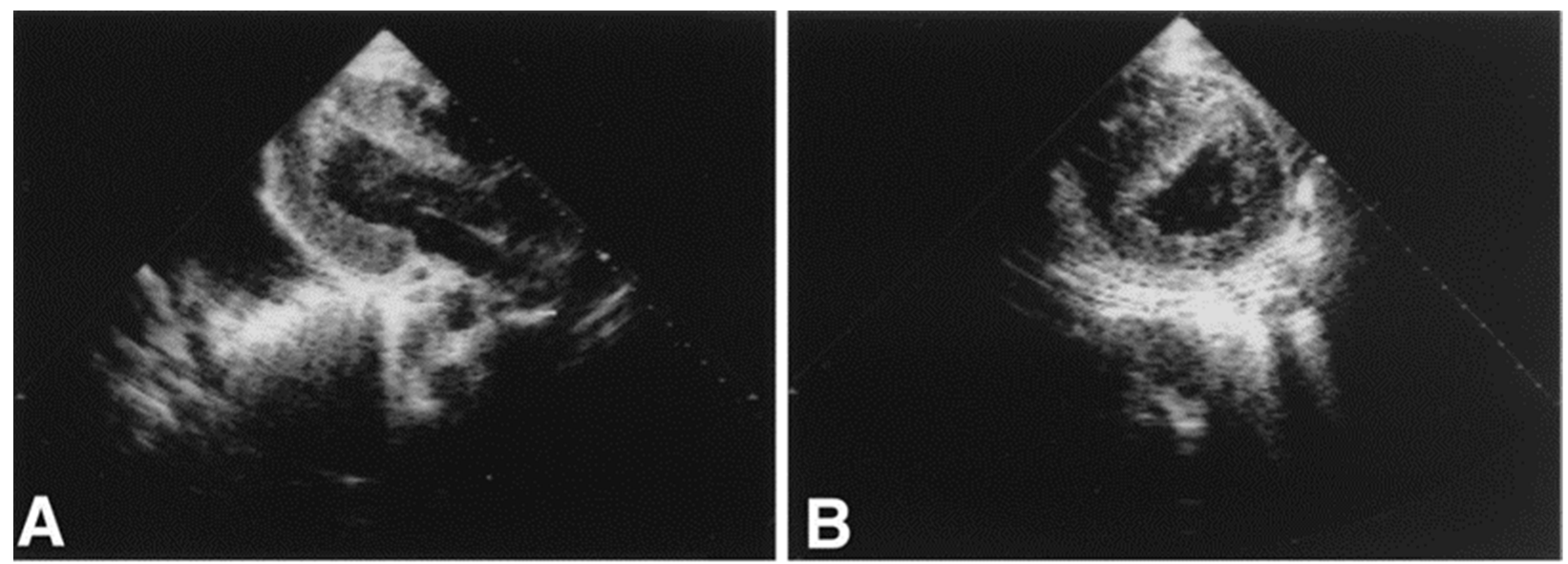

Figure 1. Two-dimensional echocardiograms from a 20-year-old man who presented after five days of a viral syndrome with acute fulminant myocarditis and acute hemodynamic collapse. The panels show parasternal long-axis (A) and short-axis (B) views. There is severe ventricular thickening (septal thickness $2.1 \mathrm{~cm}$ ) but small ventricular cavity size (LVEDD $2.5 \mathrm{~cm}$ ). The patient recovered with near-normal left ventricular function after hemodynamic support with intravenous inotropic agents and a left ventricular assist device. Reprinted with permission from Elsevier [20].

Table 1. Conventional echocardiography in viral myocarditis.

Conventional Echocardiography Findings in Viral Myocarditis:

- $\quad$ LV and RV systolic and diastolic dysfunction

- $\quad$ Regional wall motion abnormalities

- Change in LV geometry including LV dilation

- Thickening of ventricular wall due to myocardial edema

- Septal textural alteration with wall dispersion

- Pericardial effusion

LV: left ventricular, RV: right ventricular.

\subsubsection{Speckle Tracking Echocardiography}

Speckle tracking echocardiography (STE) technology has increased accuracy for the diagnosis of LV and RV systolic and diastolic dysfunction as compared to conventional 2D TTE, especially in patients with acute myocarditis. STE, with its capability to differentiate normal contractility from translation motion of the myocardium, can be used to quantify regional contractile function. STE is a time-consuming technique that requires considerable expertise and may not be readily available at most centers [21-23].

Strain and strain rate, as measured by STE, have been shown to diagnose early ventricular dysfunction and predict prognosis. Strain imaging can detect subtle LV dysfunction in patients with acute or subacute viral myocarditis, where conventional TTE showed preserved LV function.

Logstrup et al. studied left ventricular function with conventional echocardiography and STE in 28 patients diagnosed with acute myocarditis based on the Lake Louise criteria. Comparing left ventricular function with 2D echocardiography versus strain imaging, the global longitudinal $(-16.2 \pm 3.6 \%)$, epicardial longitudinal $(-14 \pm 3 \%)$, and endocardial longitudinal $(-19.4 \pm 3.9 \%)$ systolic strains were significantly reduced despite normal left ventricular function on 2D echocardiography. Strain imaging demonstrated a good correlation with the degree of myocardial edema [24]. Other case reports have demonstrated that STE measurements are more sensitive than a 2D TTE in identifying subtle regional wall motion abnormalities and diagnosing acute viral myocarditis $[25,26]$. 


\subsubsection{Tissue Doppler Imaging}

The tissue Doppler imaging (TDI) technique measures the velocity of myocardial motion instead of the velocity of blood flow. TDI is useful in assessing global and regional LV systolic function, LV diastolic function, and left ventricular filling pressures. Tissue Doppler indices tend to be abnormal in patients with acute myocarditis [27]. Urhausen et al. reported a case of myocarditis in a 31-year-old athlete with normal 2D and Doppler echocardiograms, as well as CMR. The TDI did show a net loss of systolic regional wall velocity. The diagnosis of chronic myocarditis was confirmed on EMB [28].

TDI shows promise; however, further research is still required to determine the role of TDI in acute myocarditis.

\subsubsection{Contrast Echocardiography}

Contrast echocardiography can help in the accurate assessment of left ventricular function and regional wall motion abnormalities and to detect left ventricular thrombi in acute myocarditis [29]. Afonsa et al. [30] described a case of a seventeen-year-old male with viral myopericarditis. A 2D TTE revealed a reduced left ventricular ejection fraction (LVEF) of 35\%, asymmetrical thickening of the infero-lateral wall, dyskinesis of the inferolateral wall, and a small pericardial effusion. Using a novel application of echo contrast, attenuated perfusion with delayed contrast replenishment was seen in the inferolateral segments, leading to a strong suspicion of myocarditis. A CMR study in this patient confirmed the observation noted on the echocardiogram. However, the perfusion application of contrast echocardiography is still experimental [30].

\subsubsection{Three-Dimensional (3D) Transthoracic Echocardiography}

TTE has been shown to be useful for studying and understanding complicated cardiac anatomies and hemodynamics. Its role in the diagnosis of acute viral myocarditis is not yet clear [31]. Thuny et al. reported the utility of a 3D TTE in a 43-year-old male with acute myocarditis. On a 2D TTE, the patient had LV hypokinesis with impaired LV contractility and biventricular thromboses, which were better visualized using a 3D TTE [32].

Overall, the sensitivity and specificity of these newer and more advanced echocardiographic techniques in diagnosing viral myocarditis are currently unknown and need to be studied further against cardiac magnetic resonance imaging (CMR) and EMB [17].

\subsection{Cardiac Computed Tomography}

The clinical presentation of acute viral myocarditis is extremely variable, and multidetector computed tomography (MDCT) can help in ruling out other conditions that may mimic viral myocarditis, such as ACS, aortic dissection, acute pulmonary embolism (PE), congestive heart failure, and pneumonia [33]. Acute myocarditis is associated with increased permeability of the inflamed myocardium, resulting in an increased uptake and accumulation of radiographic contrast agents. Iodinated contrast agents used with MDCT share common pharmacokinetics with the gadolinium-based contrast agents (GBCA) used with CMR. Hence, late myocardial enhancement imaging techniques used with CMR in the evaluation of acute myocarditis are also applicable to MDCT. The typical findings in acute myocarditis on MDCT are therefore similar to those of CMR, which are seen as delayed midwall or subepicardial myocardial enhancement on iodine contrast. Cardiac CT in addition can help differentiate between ACS and myocarditis by demonstrating the absence of significant coronary artery disease during the same examination. In addition, cardiac CT can also detect global and regional wall motion abnormalities of the left ventricle [33,34].

Even though CMR is considered the primary imaging technique for the diagnosis of acute myocarditis, MDCT has a few advantages over CMR [35]. MDCT is readily available and more accessible, and it has a shorter scanning time as compared to CMR. Cardiac CT imaging can provide coronary artery examination and rule out ACS in suspected patients. Moreover, it may be a reasonable alternative when CMR is not an option (e.g., in patients with metallic implants or claustrophobia) [36,37]. Bouleti et al. studied 20 patients admitted 
with chest pain and elevated troponin I, who were diagnosed with acute myocarditis by CMR. These patients then had spectral cardiac CT with late iodine enhancement (refer to Figure 2). Spectral CT showed an overall accuracy of $95 \%$ in the diagnosis of acute myocarditis compared to CMR [38]. From the limited data available, cardiac CT appears to have some useful application in viral myocarditis; however, the role of cardiac CT in acute viral myocarditis is still not well defined.

A

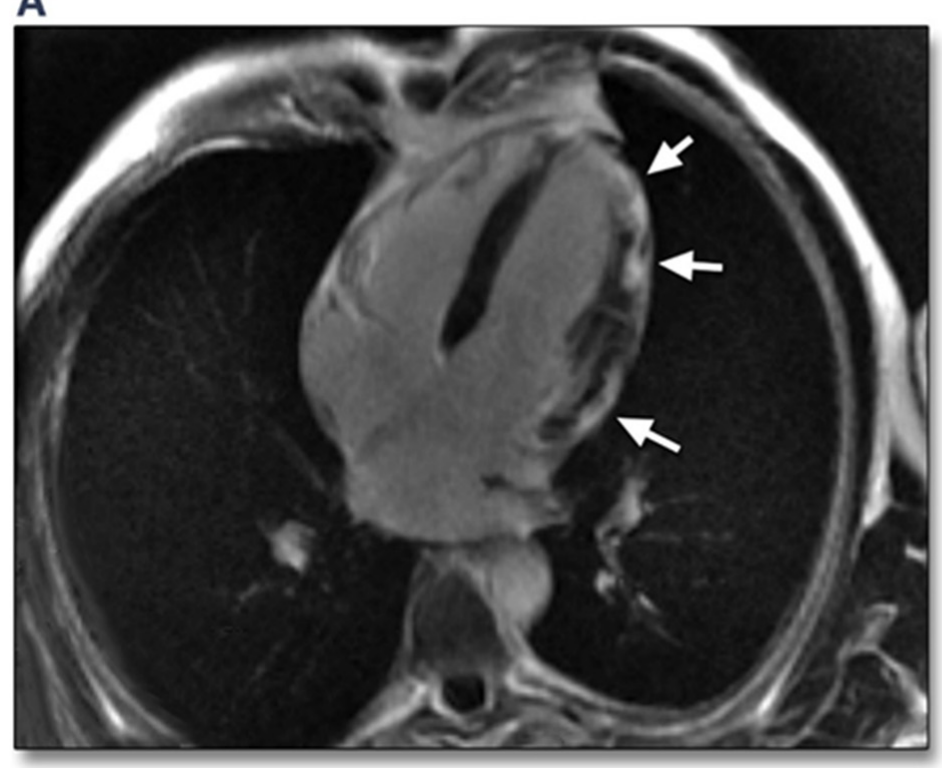

B



Figure 2. $\mathrm{CMR}$ and cardiac spectral $\mathrm{CT}$ imaging. (A) Late gadolinium enhancement imaging on cardiac magnetic resonance (CMR) in a 4-chamber view that reveals subepicardial myocardial inflammation involving the lateral and apical walls (arrows). (B) Corresponding spectral computed tomographic (CT) imaging with late iodine enhancement (arrows). Reprinted with permission from Elsevier [38].

\subsection{Cardiac Magnetic Resonance Imaging}

The histopathology of myocarditis includes inflammatory response, edema, and endothelial dysfunction, followed by myocyte necrosis and fibrosis [39]. CMR has become the leading cardiac imaging modality for tissue characterization; it has excellent spatial resolution, and acceptable interobserver variability and quantitative accuracy [40-43]. CMR is able to detect myocardial edema, hyperemia, necrosis, and fibrosis. Thus, CMR is the first choice for the assessment of myocarditis, as well as for monitoring disease activity while being treated $[39,44]$. The Lake Louise Consensus Group proposed a standard CMR protocol to identify the tissue targets in myocarditis. These diagnostic targets include edema and hyperemia, as well as necrosis and fibrosis. Any two out of the three Lake Louise criteria (LLC) establish a positive imaging diagnosis of acute myocarditis with a diagnostic accuracy of $78 \%$, a sensitivity of $67 \%$, and a specificity of $91 \%[40,45-47]$. The presence of regional or global systolic LV dysfunction and pericardial effusion are considered supportive criteria $[39,47]$.

In CMR, a T2-weighted imaging sequence is used to detect myocardial edema, conventionally obtained using black-blood spin-echo techniques. Edematous myocardium causes prolonged T2 decay times, which can be seen as hyperintense signals on T2-weighted images $[46,48,49]$. T2-weighted imaging can be evaluated using a semi-quantitative method by comparing the signal intensity (SI) of myocardium to skeletal muscle as a reference region of interest (ROI). Some studies showed that a myocardium-to-skeletal muscle SI ratio of more than 1.9 on T2-weighted CMR imaging has a sensitivity of $84 \%$, a specificity of $74 \%$, and an overall accuracy of $79 \%$ to detect significant myocarditis [46,50]. A limitation of this 
technique is the reference ROI; if the reference skeletal muscle is inflamed as seen in those with systemic inflammatory conditions, one could obtain false-negative results $[46,47,51]$.

Another CMR technique, i.e., early T1-weighted enhanced sequence, is acquired one minute after administering gadolinium. This technique relies on the detection of myocarditis-related hyperemia, and the early gadolinium enhancement (EGE) sequence shows affected areas as hyperintense signals [48,49]. Semi-quantitative methods can be used by comparing the myocardial-to-skeletal muscle SI ratio before and after giving GBCA. The EGE sequence has many limitations due to image quality inconsistency and variability in SI by using different CMR systems. Data have shown that removing this EGE criterion from the original LLC does not remarkably affect the diagnostic accuracy of myocarditis [48,49,52]. Although EGE imaging is still being used in some experienced centers, it is no longer needed as a diagnostic criterion in the revised LLC [46,47].

Late gadolinium enhancement (LGE) imaging taken ten minutes after administering GBCA shows the accumulation of gadolinium in areas of necrosis and fibrosis. Myocyte cell membrane destruction results in the passive diffusion of gadolinium from the extracellular space into the intracellular space. When delayed images are taken, the areas of inflammation appear as a hyperintense signal on T1-weighted imaging compared to normal myocardium. The patterns of LGE hyperintense signals in myocarditis are heterogeneous. The most common patterns are patchy, non-adjacent distributions seen mostly in the midmyocardial and/or subepicardial areas in the septal or lateral walls $[46,48,49,53]$. This pattern typically helps to differentiate myocarditis from ischemic cause, which is associated with subendocardial enhancement pattern. Occasionally, transmural involvement of the myocardium can be seen with extensive myocarditis. LGE imaging alone is limited given its inability to differentiate active from chronic myocarditis [46,54]. When LGE images, which detect irreversible changes of necrosis and fibrosis, are compared to T2-weighted images, which detect early changes seen in myocarditis, such as edema, the acuity of myocarditis can be estimated $[49,55,56]$.

Novel CMR techniques, particularly T1 and T2 mapping, as well as extracellular volume (ECV) quantification, have appeared to be accurate methods to characterize myocardial edema [40]. Body tissues have predictable T1 and T2 relaxation times. Any physiologic or pathologic change in tissue structure is noted as deviation from the normal T1 and T2 relaxation times. In acute myocarditis, edema causes significant prolongation of myocardial $\mathrm{T} 1$ and T2 relaxation times. These mapping techniques give quantitative data of tissue magnetic properties without subjective limitations of visual assessment of T2-weighted imaging and SI in EGE imaging [40,46]. The most commonly used methods for T2 mapping are gradient and spin echo, and for native $\mathrm{T} 1$ and $\mathrm{ECV}$ mapping, they are inversion recovery and saturation recovery sequences [46,56-61]. T2 mapping is a very reliable technique to detect myocardial edema without the disadvantages of qualitative T2-weighted imaging (see Figure 3). Since native T1 is sensitive to intra- and extra-cellular free water content, the T1 relaxation time increases in acute inflammation and hyperemia [62,63]. Native T1 mapping and ECV mapping are applicable tools for fibrosis evaluation [38]. Inflammation can be seen directly on native T1 and T2 mapping without the need to use contrast agents. When GBCA is used, combined pre-contrast and post-contrast T1 mapping can be used to quantify ECV in acute and chronic myocarditis [40,64]. However, ECV mapping is a more demanding technique, as it needs acquisition of T1 maps before and after administering GBCA and hematocrit adjustment. When compared to LGE, which detects focal fibrosis, ECV mapping can be complementary to LGE given its ability to detect milder and more diffuse myocardial fibrosis $[38,47,62,65]$. Other advantages of mapping techniques include the lack of need for a reference ROI and the shorter breath-holding time required. T1 and T2 mapping have demonstrated good sensitivity to identify myocardial inflammation $[46,47,66]$. A meta-analysis by Kotanidis et al. showed higher sensitivity of T1, T2, and ECV mapping compared to the standard CMR techniques (refer to Table 2) [67]. 


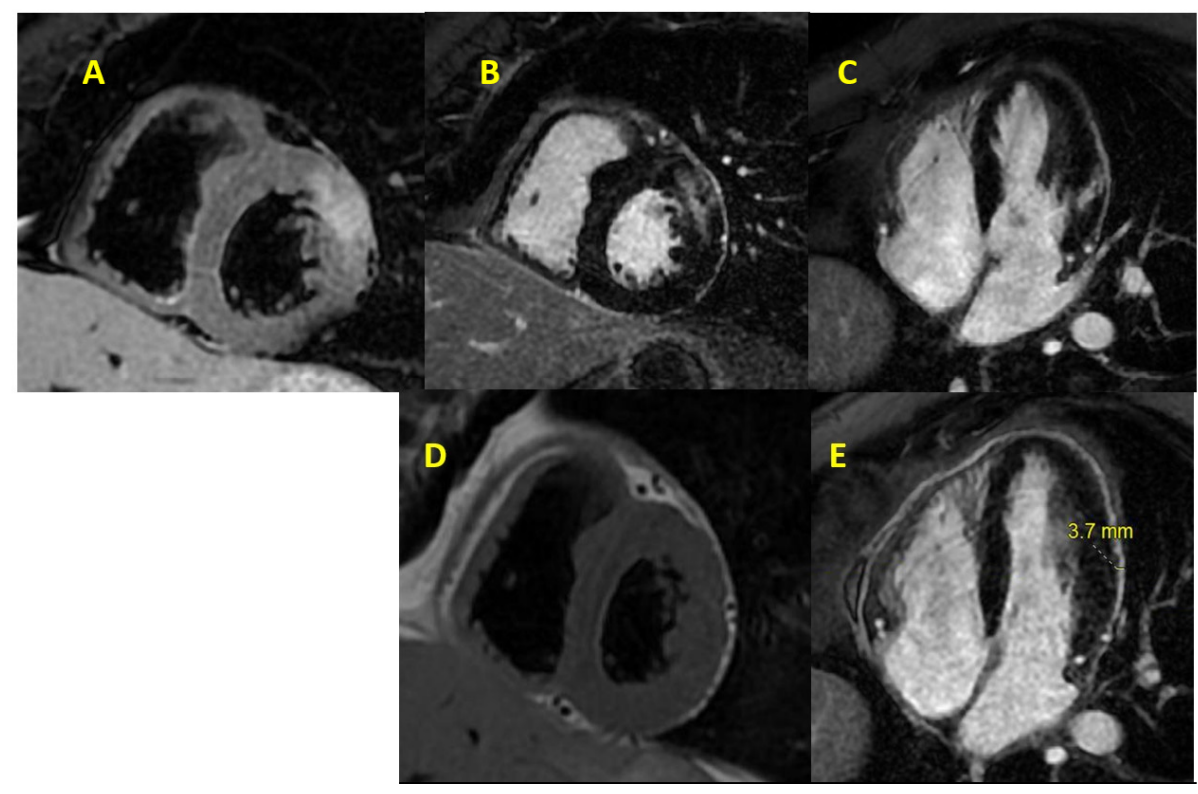

Figure 3. A case of myocarditis that was diagnosed using CMR based on the 2018 revised LLC. (A): T2-weighted image (T2 double inversion non-contrast) showing edema in the mid-myocardial segment of the anterolateral wall (non-ischemic distribution). (B) Short-axis and (C) 4-chamber view LGE images showing high signal intensity (SI) in a non-ischemic distribution in the midwall along with pericardial involvement on LGE imaging. LGE imaging taken months after treatment as seen in $(\mathbf{D}, \mathbf{E})$ when compared to $(\mathbf{B}, \mathbf{C})$, respectively, showing no myocardial scar seen on LGE with only evidence of pericardial fibrosis. Image courtesy of Neeraja Yedlapati, MD, FACC, FASE, FSCCT.

Table 2. A comparison between standard versus novel CMR techniques showing a higher sensitivity of T1, T2, and ECV mapping compared to the standard CMR techniques.

\begin{tabular}{lccc}
\hline \multicolumn{2}{c}{ Technique } & Sensitivity (\%) & Specificity (\%) \\
\hline \multirow{3}{*}{ Standard CMR Techniques } & Increased T2 signal & 68 & 91 \\
\cline { 2 - 4 } & Increased EGE & 70 & 74 \\
\cline { 2 - 4 } & Increased LGE & 68 & 96 \\
\hline \multirow{2}{*}{ Novel CMR Techniques } & T1 mapping & 89 & 90 \\
\cline { 2 - 4 } & T2 mapping & 78 & 84 \\
\cline { 2 - 4 } & ECV mapping & 75 & 76 \\
\hline
\end{tabular}

ECV: extracellular volume; EGE: early gadolinium enhancement; LGE: late gadolinium enhancement. Table derived from Kotanidis et at [67].

Another CMR novel technique is CMR image-derived myocardial strain analysis, which uses different methods to quantitatively assess myocardial deformation. Myocardial strain can help detect subtle systolic or diastolic dysfunction, which cannot be seen on routine imaging. Its diagnostic value becomes more evident when combined with $\mathrm{T} 2$ mapping and LGE $[40,68]$.

Given the remarkable evolution in CMR technology, including quantitative T1 and T2 mapping techniques, the LLC were revised in 2018 to include parametric mapping [46]. In clinically suspected myocarditis, both $\mathrm{T} 1$ and $\mathrm{T} 2$ criteria must be present according to the 2018 revised LLC (refer to Scheme 1) [46,67]. The fact that the 2018 revised LLC is a GBCA-free protocol, it has given it a great advantage over the original LLC, especially when CMR is considered in patients who cannot tolerate GBCA, such as those with an allergy to GBCA, pregnant patients, and those with end-stage renal insufficiency [38]. 


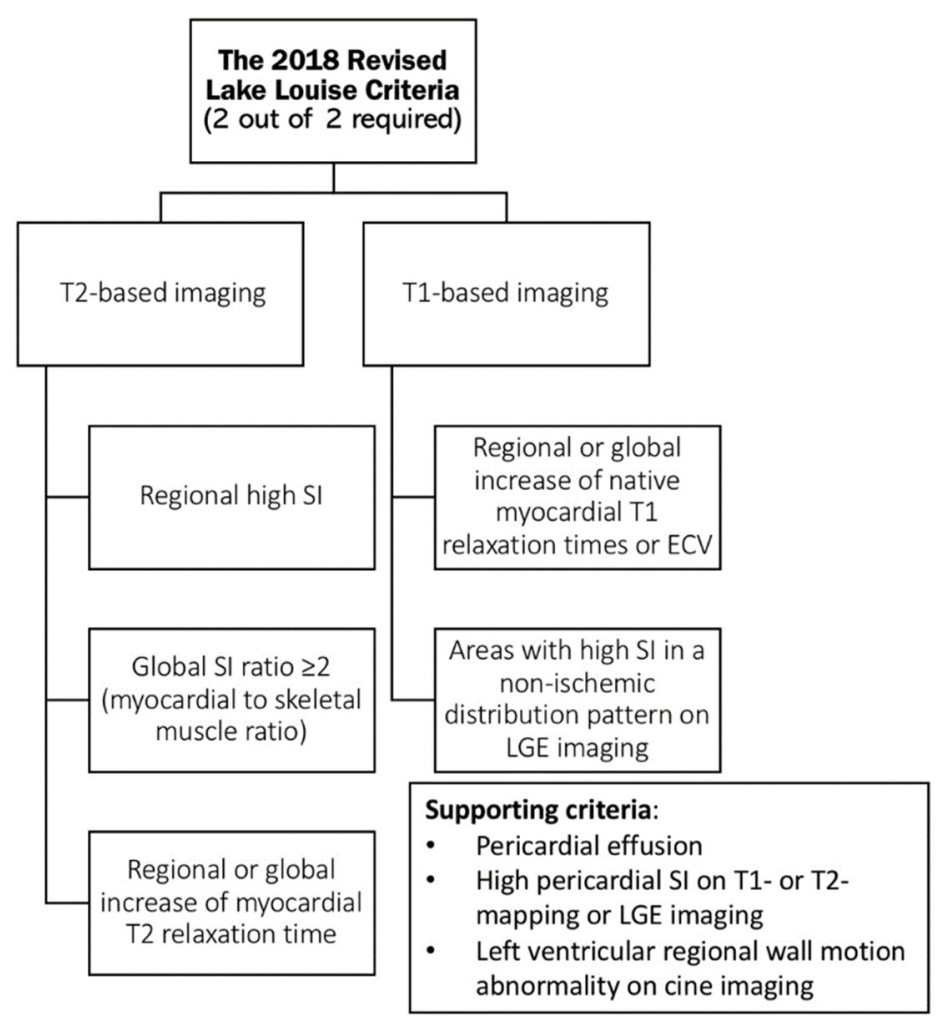

Scheme 1. The 2018 Revised Lake Louise Criteria. ECV: Extracellular volume; EGE: early gado-linium enhancement; LGE: late gadolinium enhancement; SI: signal intensity.

A study was conducted by Luetkens and colleagues to compare the 2018 revised LLC to the original LLC in diagnosing acute myocarditis. The study revealed that the 2018 revised LLC has a significantly higher sensitivity compared to the original LLC ( $87.5 \%$ vs. $72.5 \%$; $p$-value $=0.031)$, with no difference in specificity $(96.2 \%$ vs. $96.2 \% ; p$-value $=0.999)$. It concluded that the 2018 revised LLC has a better diagnostic performance of CMR in acute myocarditis $[38,46,67,69,70]$.

\subsection{Nuclear Scintigraphic Imaging}

Myocardial scintigraphy with inflammation-sensitive radioisotopes has been used to diagnose acute myocarditis [71]. The isotopes that have been used in the workup of acute myocarditis include gallium-67 (Ga-67), indium-111 (In-111) monoclonal antimyosin antibody, and technetium-99m (Tc-99m)-labeled methoxy-isobutyl isonitrile (MIBI) singlephoton emission computed tomography (SPECT), and technetium-99m depreotide [71].

Lymphocyte labeling techniques using gallium-67 scintigraphy can detect areas of inflammation in patients with myocarditis and can potentially differentiate myocarditis from acute myocardial infarction [72-74]. O'Connell et al. [73] reported a case series comparing Ga-67 scintigraphy imaging with EMB for the diagnosis of myocarditis in patients with dilated cardiomyopathy. Five out of six cases of EMB-proven myocarditis showed a dense uptake of Ga-67, suggesting that screening Ga-67 scintigraphy can increase the yield of myocardial biopsy.

Antimyosin, a monoclonal antibody against cardiac myosin, radiolabeled with In-111, has been used with scintigraphy in the diagnostic workup of acute myocarditis [75-78]. Martin et al. [79] studied antimyosin scintigraphy in 40 pediatric patients with clinically suspected myocarditis. In their observation, the uptake of antimyosin antibodies by the myocardium correlated well to the histological/pathological diagnosis of myocarditis, and persistent antimyosin uptake was associated with increased morbidity [79]. Similar observations were reported by Kuhl et al. [80]; in a study of 65 patients with clinically suspected myocarditis, monoclonal antimyosin antibody radiolabeled with In-111 uptake 
correlated well with the histoimmunopathological findings from EMB. In-111 antimyosin scintigraphy displayed excellent specificity but poor sensitivity for the detection of acute myocarditis as compared to EMB [80].

Myocardial scintigraphy with radiolabeled Tc-99m MIBI is commonly used to determine myocardial perfusion. The normal uptake and clearance of Tc-99m MIBI by myocardial cells depend on their viability and myocardial cell membrane integrity. In acute myocarditis, myocardial inflammation and necrosis result in abnormal and reduced scan uptake [16]. Sun et al. investigated 46 children with Coxsackie viral myocarditis using a Tc-99m MIBI myocardial perfusion scan, which showed areas of hypoperfusion in all patients [81]. Currently, no myocardial scintigraphy studies are available in patients with COVID-19 myocarditis.

In the recent era, CMR has become widely available and provides several advantages over nuclear imaging, and it has diminished the use of nuclear scintigraphic imaging in acute myocarditis. Some advantages of CMR over nuclear imaging include better spatial resolution, no radiation exposure, and a better correlation with histopathology [82-87].

\subsection{Combined Positron Emission Tomography and Computed Tomography (PET-CT)}

Combined 18F-fluorodeoxyglucose (18F-FDG) positron emission tomography (PET) with CT has been investigated as a tool to diagnose myocardial inflammation. One of the potential advantages of PET-CT over CMR is that it can quantify the degree of inflammation, leading to close monitoring of the disease course and the response to anti-inflammatory and immunosuppressive therapies. PET-CT can be considered as an alternative study in patients with contraindications to CMR [88]. Researchers have looked at simultaneous/hybrid cardiac PET-CT/CMR imaging and found that they complement each other in the assessment of myocarditis compared to either approach alone [89]. A number of case reports have demonstrated the use of PET-CT in conditions resulting in myocardial inflammation, such as cardiac sarcoidosis, viral myocarditis, giant cell myocarditis, and post-infarction myocarditis [90-96]. One prospective study investigated the use of PET-CT as compared to CMR with LGE in 65 patients with suspected myocarditis. It showed that the sensitivity and specificity of PET-CT was $74 \%$ and $97 \%$, respectively, with an overall accuracy of $87 \%$ as compared to CMR [97]. A clinical trial that is underway plans to assess patients with clinically suspected myocarditis using TTE, nuclear SPECT imaging, and 18F-FDG PET-CT. Right ventricular biopsies will be performed and will be the gold standard for analysis. The trial is designed to look at the sensitivity and specificity of 18F-FDG PET-CT imaging in diagnosing acute myocarditis [98].

\section{The Role of Imaging in Determining Prognosis in Acute Myocarditis}

Most cases of acute myocarditis tend to regress over time, leaving no or only mild functional damage. However, acute fulminant myocarditis is associated with a much worse outcome and more residual damage [12,20].

A retrospective, single-center, observational study of 112 patients diagnosed with acute myocarditis by CMR, studied the primary endpoint of major adverse cardiovascular events (MACE), which included all-cause mortality, cardiac mortality, the recurrence of myocarditis, heart failure, and sustained ventricular tachycardia. The MACE rate was significantly higher in those with extensive LGE on CMR, as defined as those with LGE of more than $17 \mathrm{~g}$, compared to those with LGE less than $17 \mathrm{~g}$ (MACE rate of $17 \%$ vs. $4 \% ; p$-value $=0.005$ ). Moreover, those who initially presented with an infarct-like pattern of myocarditis, defined as those who presented with chest pain, ST elevation on ECG, and elevated cardiac enzymes (troponin), were noted to have an increased risk of MACE recurrence and particularly sustained ventricular tachycardia. During a median follow up of 16 months, those with initial symptoms that correlated with New York Heart Association (NYHA) class III or IV and LGE of more than $17 \mathrm{~g}$ on CMR were independent predictors of MACE occurrence after acute myocarditis [99]. 
Based on two meta-analyses, CMR might be a helpful tool in determining the longterm prognosis of acute myocarditis. They were able to show that LGE and LVEF are strong predictors of MACE, defined as all-cause mortality, cardiac mortality, the recurrence of myocarditis, heart failure, and sustained ventricular tachycardia. However, using cut-off values of LGE (17 $\mathrm{g}$ or $13 \%$ of myocardial mass) is not a validated approach to be applied in routine clinical practice $[99,100]$. In a study of 374 patients with acute myocarditis and normal LVEF, the location of LGE determined prognosis; LGE seen in the midwall of the anteroseptal segment is associated with a worse prognosis than LGE seen in other segments [101]. There is no current evidence to support the use of the novel CMR techniques (T2, T1, and ECV mapping) to determine the prognosis of those with acute myocarditis [39].

\section{COVID-19-Related Myocarditis}

COVID-19 disease is caused by severe acute respiratory syndrome coronavirus 2 (SARS-CoV-2). This novel virus came to the forefront of global attention in December 2019 after it was found to cause ARDS in patients from Hubei province in China [7]. With the spread of the virus to countries all over the world and an increasing number of cases, the World Health Organization declared COVID-19 a global pandemic on March, eleventh 2020 [102].

COVID-19 has multisystem involvement, including the cardiovascular system. Acute myocarditis is a recognized complication of COVID-19, although the exact mechanism is not well known. Myocardial injury and ischemic necrosis can be caused be a number of different mechanisms, including direct involvement by the SARS-CoV-2 virus and indirect involvement with myocardial damage caused by coronary thrombosis, coronary plaque rupture, cytokine storm with systemic inflammation, hypoxia, relative ischemia from a supply/demand mismatch, and electrolyte derangements [103]. Only a small number of cases suggesting direct viral involvement of cardiac myocytes resulted in viral myocarditis [104,105].

The clinical presentation of COVID-19 cardiac disease can be heterogeneous, ranging from an asymptomatic cardiac biomarker elevation to severe disease in the form of acute cardiogenic shock and cardiac arrest [105]. Clinically elevated cardiac biomarkers, i.e., serum troponin and BNP, abnormal EKG, and new left ventricular dysfunction, can raise the suspicion of COVID-19 myocarditis; however, an endomyocardial biopsy is the only diagnostic modality for COVID-19 myocarditis.

\section{Imaging in COVID-19}

In the acute setting of acute COVID-19 pneumonia, diagnosing acute myocarditis can be very challenging. An abnormal EKG and elevated cardiac biomarkers can raise the suspicion of COVID-19 myocarditis.

The causal relationship of myocarditis with COVID-19 can be very difficult to determine, especially in the setting of ARDS while dealing with an unstable and ventilated population [106-108]. Advanced imaging might be necessary to support the diagnosis of myocarditis and can perhaps help to differentiate between cardiovascular and pulmonary causes of such an overlapping presentation of COVID-19 infection [109]. A pandemic of a highly contagious pathogen poses an important ethical dilemma; i.e., one has to be judicious while ordering cardiac imaging in patients with a highly contagious infection to prevent the risk of transmission to the operators and staff members. Reports have shown that echocardiography poses a higher risk of transmitting COVID-19 when compared to CMR. It is critical for the staff to practice and adhere to protective measures, including the proper use of personal protective equipment (PPE) and the disinfecting of equipment (ultrasound probe and scanners) and imaging rooms [109-112]. It is of paramount importance to minimize the time of exposure by performing only a focused echocardiogram rather than a full exam in patients under investigation (PUI) or confirmed COVID-19 patients $[113,114]$.

Despite the clues of myocarditis on imaging, EMB is considered to be the gold standard for the diagnosis of myocarditis. The findings of EMB on the histopathology of COVID-19- 
related myocarditis have been described as cellular infiltrates with necrotic areas. EMB and autopsy specimen findings do not show any specific or reproducible pattern of COVID19 myocarditis. In addition, some case reports early in the pandemic did not show any direct viral involvement of the myocardium on EMB or even autopsy. In some reports, the viral genome was detected on tissue specimens [103]. The current ESC guidelines do not recommend cardiac biopsy for COVID-19 patients with suspected myocarditis [112]. The limited role of EMB makes noninvasive cardiac imaging modalities more vital to diagnose COVID-19-related myocarditis.

\subsection{Transthoracic Echocardiography in COVID-19}

Given its low cost, bedside availability, and portability, TTE is considered to be the initial imaging modality in suspected myocarditis in COVID-19-related ARDS. Many hospitals have dedicated ultrasound machines to be used only in COVID-19 units [110,112-116]. The ESC Working Group on Myocardial and Pericardial Diseases recommended a TTE as part of the initial workup for all COVID-19 patients with suspected myocarditis [12,63,111]. Left ventricular or biventricular dysfunction, altered ventricular global strain, myocardial edema, LV thrombus, and pericardial effusion can be seen in myocarditis related to COVID-19 but are nonspecific findings (see Figure 4) [105,117].

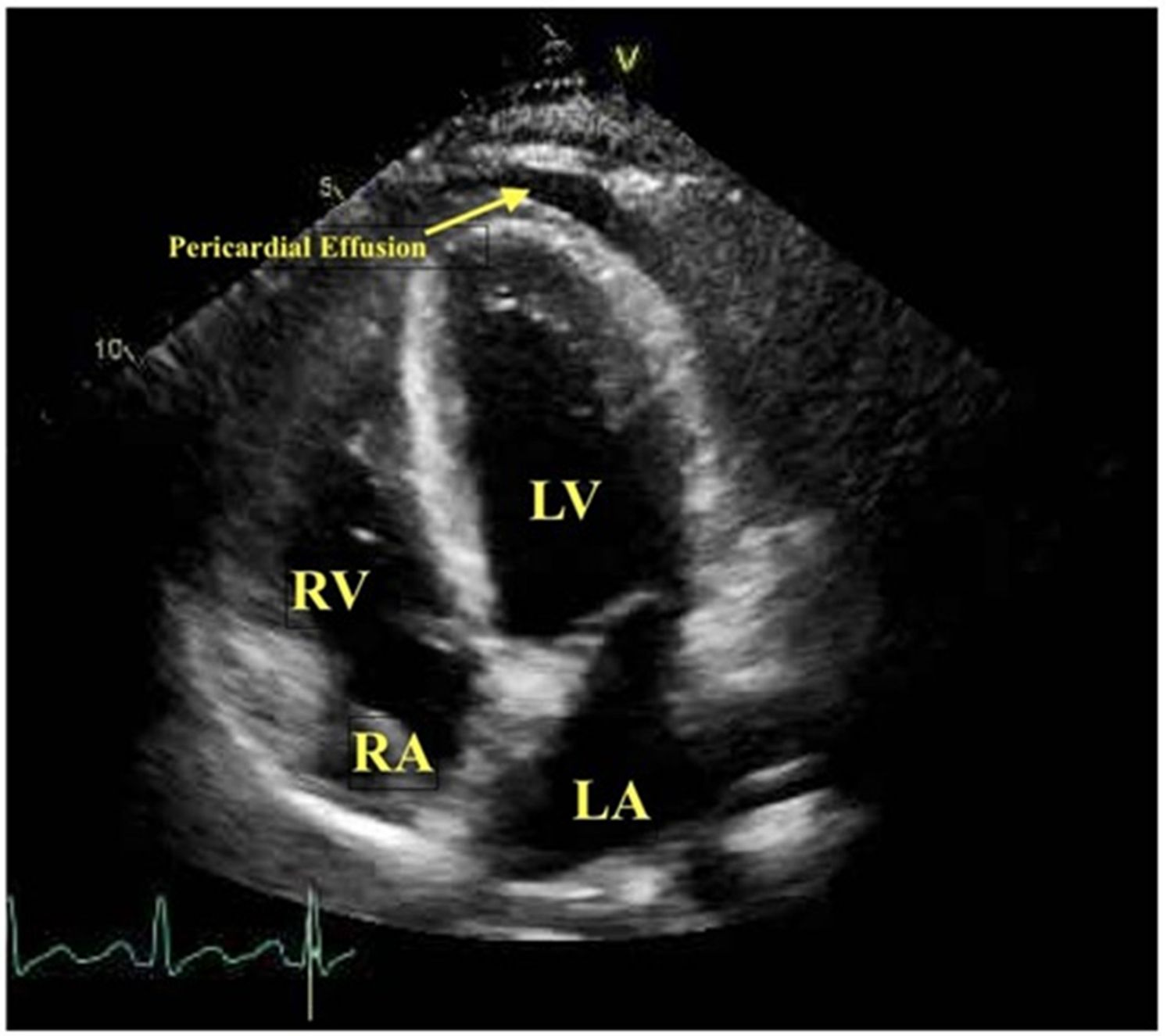

Figure 4. Four-chamber view of transthoracic echocardiogram of a 30-year-old female presenting with cardiogenic shock secondary to COVID-19 myocarditis. The ejection fraction was reduced at $45 \%$ with moderate diffuse hypokinesis, grade I diastolic dysfunction, and pericardial effusion. Reprinted with permission from Oxford University Press [105]. 
A systematic review by Rathore et al. examined data from case reports and a case series of 42 patients with COVID-19-related myocarditis. TTE was performed in 35 patients, $74 \%$ of whom showed low LVEF with a mean of $37 \%$. Other important echocardiographic features included LV hypokinesis (37.2\%) and pericardial effusion (26\% of patients) [118].

In a large series of 218 COVID-19 patients with no underlying cardiac disease, speckle tracking echocardiography demonstrated abnormal strain, i.e., reduced global longitudinal shortening in $83 \%$ of patients, while only $22 \%$ of patients were noticed to have left ventricular dysfunction on 2D echocardiography [119]. A reduced GLS was more commonly seen in critically ill patients (98\% vs. $78.3 \%, p<0.001)$. The average GLS was $-13.7 \% \pm 3.4 \%$ vs. $-17.4 \% \pm 3.2 \%, p<0.001$ in the critically ill patients as compared to noncritical patients. The distribution of the strain was noticed more in the subendocardial regions, which is a typical pattern of myocarditis. The changes in GLS correlated significantly to clinical and inflammatory markers, such as pulse oxygen saturation, high-sensitive C-reactive protein, and inflammatory cytokines, especially in sicker patients [119]. Another retrospective study from Croft et al. studied LV GLS in 58 non-consecutive patients hospitalized with COVID-19 infection. The mean LV ejection fraction (LVEF) and LV GLS was 52.1 and $-12.9 \pm 4.0 \%$, respectively. In the 30 patients with preserved LVEF ( $>50 \%)$, LV GLS was also reduced $(-15.7 \pm 2.8 \%)$ compared to the healthy population. Data from these studies indicate that acute myocardial injury may be subtle in patients with COVID-19 and that strain imaging can be useful for the identification of occult myocardial injury [120].

In a case report by Trogen et al. of a 17-year-old patient with SARS-CoV-2-related acute myocarditis, confirmed by echocardiography and cardiac magnetic resonance imaging, tissue Doppler abnormalities and abnormal strain were present even after one week of discharge [121]. These observations suggest that some of the sequelae related to COVID-19 myocarditis can be persistent. More studies are required to understand if these changes will reverse after some time or whether they will lead to permanent dysfunction.

Advanced echo techniques, such as strain imaging and tissue Doppler imaging, can be used as gatekeeper tests to identify patients who can benefit from CMR and EMB for the diagnosis and follow-up of COVID-19 myocarditis [122,123].

\subsection{Cardiac Computerized Tomography in COVID-19}

The presentation of COVID-19 has overlapping cardiac and respiratory involvement. Moreover, acute PE is very common in COVID-19 pneumonia and can also present with an abnormal EKG and elevated biomarkers; however, these patients tend to have severe hypoxemia and tachycardia disproportionate to the degree of pneumonia. Cardiac CTA can be a one-stop shop for the diagnosis of acute PE, excluding coronary artery disease [124,125], as well as for the assessment of the severity of pulmonary disease.

The utilization of cardiac CTA in COVID-19 patients can prevent unnecessary coronary angiograms and the exposure of cardiac catheterization laboratory personnel to COVID19 [126]. A delayed post-iodine contrast CT scan be useful for tissue characterization in COVID-19-related myocarditis [127]. One health care system in New York reported their experience of using CCTA to evaluate patients presenting with acute chest pain during the COVID-19 pandemic. They detected two cases of acute peri-myocarditis among ten confirmed COVID-19-positive patients using CCTA [128].

CT is limited in identifying myocardial edema. Due to its inability to null the signal from normal myocardial tissue, CT with delayed enhancement is still inferior to CMR [129-131]. The ESC, the European Association of Cardiovascular Imaging (EACVI), and the Society of Cardiovascular Computed Tomography (SCCT) have recommended the use of CCTA in COVID-19 patients with acute chest pain, especially if it is expected to impact their management $[112,132,133]$. Further studies about CCTA are still needed to provide more information on its utility in managing COVID-19 patients with cardiac involvement. 


\subsection{Cardiac Magnetic Resonance Imaging in COVID-19}

CMR is considered the gold standard, noninvasive diagnostic tool for suspected myocarditis [36,134]. Key findings in COVID-19 myocarditis include myocardial edema, myocardial necrosis, LGE, and RV dysfunction [135]. Panchal et al. reported that, from their experience, CMR demonstrated more diffuse myocardial involvement in COVID-19-related myocarditis as compared to non-COVID-19 myocarditis [136].

In a large cohort of 100 German patients who recovered from COVID-19, abnormal myocardial findings were noted in $78 \%$ of them, which included myocardial edema, LGE, and pericardial enhancement [137]. In CMR of 26 college athletes who recovered from COVID, $15 \%$ of them $(n=4)$ met the updated LLC criteria for myocarditis, i.e., the presence of myocardial edema and myocardial injury by LGE. An additional $46 \%$ of the athletes were found to have late gadolinium enhancement alone [138]. On the screening of 1597 athletes who recovered from COVID-19, $2.3 \%$ of them were found to have findings consistent with COVID-19 myocarditis (9 had clinical symptoms and 27 had subclinical symptoms of myocarditis). These observations support the fact that the use of CMR can improve the detection of COVID-19 myocarditis, particularly in individuals with subclinical symptoms [139].

A midterm follow-up of recovered COVID-19 patients showed that LGE was present in $30 \%$ of the patient population. These patients tend to have a lower LV circumferential strain and abnormal RV strain parameters [140]. The presence of an abnormal myocardial pattern after complete recovery from COVID-19 suggests that there might be long-term cardiac sequelae of COVID-19 infection, which are largely unknown.

CMR has its own challenges, which include scant availability; cost; exam length; and patient-related challenges, such as arrhythmia, inability to hold breath, claustrophobia, implanted metallic devices, and contrast allergy $[63,68,141]$. CMR testing is very challenging in COVID-19 patients who are intubated. Experts recommend performing a focused CMR using specific sequences instead of a comprehensive exam to reduce CMR time. This can be achieved through using a modern magnet. A short protocol CMR with the acquisition of T2 mapping and steady-state free precession (SSFP) are enough to evaluate regional wall motion abnormalities, systolic function, chambers size and volume, and the presence of edema. Once patients are more stable and no longer infectious, a complete CMR protocol with LGE can be carried out to assess for fibrosis [63,142].

\subsection{Nuclear Imaging in COVID-19}

Nuclear cardiology imaging techniques require a long acquisition time and special protocols, which increase the risk of contracting COVID-19. In COVID-19 patients, the use of nuclear cardiology imaging modalities should be limited to those with a clinical suspicion of cardiac involvement when other imaging modalities cannot be used or are contraindicated. Examples include those with prosthetic valves or intracardiac devices $[109,143]$. The role of PET-CT in COVID-19-associated myocarditis is not clear. There are some reports on the use of PET-CT in COVID-19 patients that look specifically at acute respiratory disease where lung involvement, seen as acute lung inflammation, is detected on PET-CT. Given the fact that PET-CT can detect acute viral myocarditis, it is possible to apply that to COVID-19-related myocarditis [144,145].

The role of combined cardiac CT and 18F-FDG PET-CT in COVID-19 infections is currently being evaluated against the gold standard CMR. The primary endpoint of the study is the proportion of COVID-19 subjects with cardiovascular injury within two weeks of admission [146]. More data and studies are still needed to clarify the role and applicability of 18F-FDG PET-CT scanning in COVID-19-related myocarditis.

\section{Conclusions}

Cardiovascular disease secondary to SARS-CoV-2 includes acute myocarditis and is associated with significant morbidity and mortality. An accurate diagnosis of acute viral myocarditis is very challenging with the heterogeneous presentation of the disease. 
Despite its own disadvantages, EMB is considered to be the gold standard diagnostic test. Myocardial involvement in viral myocarditis is focal and patchy, which explains the low sensitivity and diagnostic accuracy of EMB. Therefore, noninvasive cardiac imaging is an essential part of the workup of acute viral myocarditis. CMR is considered to be the most useful noninvasive test to detect myocarditis and can give detailed information in terms of myocardial structure and function. Noninvasive imaging modalities, such as TTE, along with strain imaging and tissue Doppler analysis, can help to identify myocardial abnormalities, which can be subsequently confirmed with CMR. At present, the role of CT in the diagnosis of COVID-19 myocarditis is not known.

Nuclear imaging can be helpful to identify myocardial scar; however, the role of nuclear imaging will remain limited in the era of CMR. The proper use of PPE and meticulous decontamination techniques is essential in reducing the risk of viral transmission of this highly contagious virus. Further research is needed to improve our understanding, approach, management, and follow-up of COVID-19-related myocarditis.

Author Contributions: Conceptualization, A.A., N.G.; writing-original draft preparation, D.A., A.B.; writing-review and editing, A.A., N.Y., N.G.; supervision, A.A., N.Y., N.G. All authors have read and agreed to the published version of the manuscript.

Funding: This research received no external funding.

Institutional Review Board Statement: Not applicable.

Informed Consent Statement: Not applicable.

Data Availability Statement: Not applicable.

Conflicts of Interest: The authors declare no conflict of interest.

\section{Abbreviations}

$\begin{array}{ll}\text { 18F-FDG } & \text { 18F-fluorodeoxyglucose } \\ \text { ACS } & \text { Acute coronary syndrome } \\ \text { ARDS } & \text { Acute respiratory distress syndrome } \\ \text { CCTA } & \text { Coronary computed tomography angiography } \\ \text { CMR } & \text { Cardiac magnetic resonance } \\ \text { COVID-19 } & \text { Coronavirus disease 2019 } \\ \text { CT } & \text { Computed tomography } \\ \text { ECG } & \text { Electrocardiogram } \\ \text { ECV } & \text { Extracellular volume } \\ \text { EGE } & \text { Early gadolinium enhancement } \\ \text { EMB } & \text { Endomyocardial biopsy } \\ \text { GBCA } & \text { Gadolinium-based contrast agent } \\ \text { LGE } & \text { Late gadolinium enhancement } \\ \text { LLC } & \text { Lake Louise criteria } \\ \text { LV } & \text { Left ventricle } \\ \text { LVEF } & \text { Left ventricular ejection fraction } \\ \text { PE } & \text { Pulmonary embolism } \\ \text { PET } & \text { Positron emission tomography } \\ \text { PPE } & \text { Personal protective equipment } \\ \text { RV } & \text { Right ventricle } \\ \text { SARS-CoV-2 } & \text { Severe acute respiratory syndrome coronavirus 2 } \\ \text { SPECT } & \text { Single-photon emission computed tomography } \\ \text { STE } & \text { Speckle tracking echocardiography } \\ \text { TDI } & \text { Tissue Doppler imaging } \\ \text { TTE } & \text { Transthoracic echocardiography }\end{array}$




\section{References}

1. Blauwet, L.A.; Cooper, L.T. Myocarditis. Prog. Cardiovasc. Dis. 2010, 52, 274-288. [CrossRef] [PubMed]

2. Tschöpe, C.; Ammirati, E.; Bozkurt, B.; Caforio, A.L.P.; Cooper, L.T.; Felix, S.B.; Hare, J.M.; Heidecker, B.; Heymans, S.; Hübner, N.; et al. Myocarditis and inflammatory cardiomyopathy: Current evidence and future directions. Nat. Rev. Cardiol. 2021, 18, 169-193. [CrossRef] [PubMed]

3. Caforio, A.L.; Calabrese, F.; Angelini, A.; Tona, F.; Vinci, A.; Bottaro, S.; Ramondo, A.; Carturan, E.; Iliceto, S.; Thiene, G.; et al. A prospective study of biopsy-proven myocarditis: Prognostic relevance of clinical and aetiopathogenetic features at diagnosis. Eur. Heart J. 2007, 28, 1326-1333. [CrossRef] [PubMed]

4. Ammirati, E.; Frigerio, M.; Adler, E.D.; Basso, C.; Birnie, D.H.; Brambatti, M.; Friedrich, M.G.; Klingel, K.; Lehtonen, J.; Moslehi, J.J.; et al. Management of Acute Myocarditis and Chronic Inflammatory Cardiomyopathy: An Expert Consensus Document. Circ. Heart Fail. 2020, 13, e007405. [CrossRef]

5. Cooper, L.T., Jr. Myocarditis. N. Engl. J. Med. 2009, 360, 1526-1538. [CrossRef]

6. Schultz, J.C.; Hilliard, A.A.; Cooper, L.T., Jr.; Rihal, C.S. Diagnosis and treatment of viral myocarditis. Mayo Clin. Proc. 2009, 84, 1001-1009. [CrossRef]

7. Ruan, Q.; Yang, K.; Wang, W.; Jiang, L.; Song, J. Clinical predictors of mortality due to COVID-19 based on an analysis of data of 150 patients from Wuhan, China. Intensive Care Med. 2020, 46, 846-848. [CrossRef]

8. Oleszak, F.; Maryniak, A.; Botti, E.; Abrahim, C.; Salifu, M.O.; Youssef, M.; Henglein, V.L.; McFarlane, S.I. Myocarditis Associated With COVID-19. Am. J. Med. Case Rep. 2020, 8, 498-502. [CrossRef]

9. Tahir, F.; Bin Arif, T.; Ahmed, J.; Malik, F.; Khalid, M. Cardiac Manifestations of Coronavirus Disease 2019 (COVID-19): A Comprehensive Review. Cureus 2020, 12, e8021. [CrossRef]

10. Rose, N.R. Viral myocarditis. Curr. Opin. Rheumatol. 2016, 28, 383-389. [CrossRef]

11. Cooper, L.T.; Baughman, K.L.; Feldman, A.M.; Frustaci, A.; Jessup, M.; Kuhl, U.; Levine, G.N.; Narula, J.; Starling, R.C.; Towbin, J.; et al. The role of endomyocardial biopsy in the management of cardiovascular disease: A scientific statement from the American Heart Association, the American College of Cardiology, and the European Society of Cardiology. Circulation 2007, 116, 2216-2233. [CrossRef] [PubMed]

12. Ammirati, E.; Veronese, G.; Cipriani, M.; Moroni, F.; Garascia, A.; Brambatti, M.; Adler, E.D.; Frigerio, M. Acute and Fulminant Myocarditis: A Pragmatic Clinical Approach to Diagnosis and Treatment. Curr. Cardiol. Rep. 2018, 20, 114. [CrossRef] [PubMed]

13. Caforio, A.L.P.; Pankuweit, S.; Arbustini, E.; Basso, C.; Gimeno-Blanes, J.; Felix, S.B.; Fu, M.; Heliö, T.; Heymans, S.; Jahns, R.; et al. Current state of knowledge on aetiology, diagnosis, management, and therapy of myocarditis: A position statement of the European Society of Cardiology Working Group on Myocardial and Pericardial Diseases. Eur. Heart J. 2013, 34, $2636-2648$. [CrossRef] [PubMed]

14. Douglas, P.S.; Khandheria, B.; Stainback, R.F.; Weissman, N.J.; Brindis, R.G.; Patel, M.R.; Khandheria, B.; Alpert, J.S.; Fitzgerald, D.; Heidenreich, P.; et al. ACCF/ASE/ACEP/ASNC/SCAI/SCCT/SCMR 2007 appropriateness criteria for transthoracic and transesophageal echocardiography: A report of the American College of Cardiology Foundation Quality Strategic Directions Committee Appropriateness Criteria Working Group, American Society of Echocardiography, American College of Emergency Physicians, American Society of Nuclear Cardiology, Society for Cardiovascular Angiography and Interventions, Society of Cardiovascular Computed Tomography, and the Society for Cardiovascular Magnetic Resonance endorsed by the American College of Chest Physicians and the Society of Critical Care Medicine. J. Am. Coll. Cardiol. 2007, 50, 187-204. [CrossRef] [PubMed]

15. Malik, S.B.; Chen, N.; Parker, R.A., III; Hsu, J.Y. Transthoracic Echocardiography: Pitfalls and Limitations as Delineated at Cardiac CT and MR Imaging. RadioGraphics 2017, 37, 383-406. [CrossRef] [PubMed]

16. Bière, L.; Piriou, N.; Ernande, L.; Rouzet, F.; Lairez, O. Imaging of myocarditis and inflammatory cardiomyopathies. Arch. Cardiovasc. Dis. 2019, 112, 630-641. [CrossRef] [PubMed]

17. Jeserich, M.; Konstantinides, S.; Pavlik, G.; Bode, C.; Geibel, A. Non-invasive imaging in the diagnosis of acute viral myocarditis. Clin. Res. Cardiol. 2009, 98, 753-763. [CrossRef] [PubMed]

18. Escher, F.; Kasner, M.; Kühl, U.; Heymer, J.; Wilkenshoff, U.; Tschöpe, C.; Schultheiss, H.P. New echocardiographic findings correlate with intramyocardial inflammation in endomyocardial biopsies of patients with acute myocarditis and inflammatory cardiomyopathy. Mediat. Inflamm. 2013, 2013, 875420. [CrossRef]

19. Pinamonti, B.; Alberti, E.; Cigalotto, A.; Dreas, L.; Salvi, A.; Silvestri, F.; Camerini, F. Echocardiographic findings in myocarditis. Am. J. Cardiol. 1988, 62, 285-291. [CrossRef]

20. Felker, G.M.; Boehmer, J.P.; Hruban, R.H.; Hutchins, G.M.; Kasper, E.K.; Baughman, K.L.; Hare, J.M. Echocardiographic findings in fulminant and acute myocarditis. J. Am. Coll. Cardiol. 2000, 36, 227-232. [CrossRef]

21. Hsiao, J.F.; Koshino, Y.; Bonnichsen, C.R.; Yu, Y.; Miller, F.A., Jr.; Pellikka, P.A.; Cooper, L.T., Jr.; Villarraga, H.R. Speckle tracking echocardiography in acute myocarditis. Int. J. Cardiovasc. Imaging 2013, 29, 275-284. [CrossRef] [PubMed]

22. Nesukay, E.; Kovalenko, V.; Cherniuk, S.; Danilenko, A. The diagnostic value of speckle-tracking echocardiography in myocarditis and dilated cardiomyopathy. Eur. Heart J. 2013, 34 (Suppl. 1), 3866. [CrossRef]

23. Matshela, M.R. The role of echocardiography in acute viral myocarditis. Cardiovasc. J. Afr. 2019, 30, 239-244. [CrossRef]

24. Løgstrup, B.B.; Nielsen, J.M.; Kim, W.Y.; Poulsen, S.H. Myocardial oedema in acute myocarditis detected by echocardiographic 2D myocardial deformation analysis. Eur. Heart J. Cardiovasc. Imaging 2016, 17, 1018-1026. [CrossRef] [PubMed] 
25. Sturmberger, T.; Niel, J.; Aichinger, J.; Ebner, C. Acute myocarditis with normal wall motion detected with 2D speckle tracking echocardiography. Echo Res. Pract. 2016, 3, K15-K19. [CrossRef] [PubMed]

26. Tünnemann-Tarr, A.; Stöbe, S.; Laufs, U.; Hagendorff, A.; Tayal, B. Speckle tracking echocardiography in a patient with viral myocarditis and acute myocardial infarction. J. Cardiol. Cases 2020, 22, 184-191. [CrossRef] [PubMed]

27. Escher, F.; Westermann, D.; Gaub, R.; Pronk, J.; Bock, T.; Al-Saadi, N.; Kühl, U.; Schultheiss, H.P.; Tschöpe, C. Development of diastolic heart failure in a 6-year follow-up study in patients after acute myocarditis. Heart 2011, 97, 709-714. [CrossRef]

28. Urhausen, A.; Kindermann, M.; Bohm, M.; Kindermann, W. Images in cardiovascular medicine. Diagnosis of myocarditis by cardiac tissue velocity imaging in an olympic athlete. Circulation 2003, 108, e21-e22. [CrossRef]

29. Olszewski, R.; Timperley, J.; Szmigielski, C.; Monaghan, M.; Nihoyannopoulos, P.; Senior, R.; Becher, H. The clinical applications of contrast echocardiography. Eur. J. Echocardiogr. 2007, 8, S13-S23. [CrossRef]

30. Afonso, L.; Hari, P.; Pidlaoan, V.; Kondur, A.; Jacob, S.; Khetarpal, V. Acute myocarditis: Can novel echocardiographic techniques assist with diagnosis? Eur. J. Echocardiogr. 2010, 11, E5. [CrossRef]

31. Shiota, T. 3D echocardiography: The present and the future. J. Cardiol. 2008, 52, 169-185. [CrossRef] [PubMed]

32. Thuny, F.; Avierinos, J.F.; Jop, B.; Tafanelli, L.; Renard, S.; Riberi, A.; Métras, D.; Habib, G. Images in cardiovascular medicine. Massive biventricular thrombosis as a consequence of myocarditis: Findings from 2-dimensional and real-time 3-dimensional echocardiography. Circulation 2006, 113, e932-e933. [CrossRef] [PubMed]

33. Budoff, M.J.; Dowe, D.; Jollis, J.G.; Gitter, M.; Sutherland, J.; Halamert, E.; Scherer, M.; Bellinger, R.; Martin, A.; Benton, R.; et al. Diagnostic performance of 64-multidetector row coronary computed tomographic angiography for evaluation of coronary artery stenosis in individuals without known coronary artery disease: Results from the prospective multicenter ACCURACY (Assessment by Coronary Computed Tomographic Angiography of Individuals Undergoing Invasive Coronary Angiography) trial. J. Am. Coll. Cardiol. 2008, 52, 1724-1732. [CrossRef] [PubMed]

34. Schuleri, K.H.; George, R.T.; Lardo, A.C. Applications of cardiac multidetector CT beyond coronary angiography. Nat. Rev. Cardiol. 2009, 6, 699-710. [CrossRef]

35. Choi, S.I.; George, R.T.; Schuleri, K.H.; Chun, E.J.; Lima, J.A.; Lardo, A.C. Recent developments in wide-detector cardiac computed tomography. Int. J. Cardiovasc. Imaging 2009, 25 (Suppl. 1), 23-29. [CrossRef]

36. Friedrich, M.G.; Sechtem, U.; Schulz-Menger, J.; Holmvang, G.; Alakija, P.; Cooper, L.T.; White, J.A.; Abdel-Aty, H.; Gutberlet, M.; Prasad, S.; et al. Cardiovascular magnetic resonance in myocarditis: A JACC White Paper. J. Am. Coll. Cardiol. 2009, 53, $1475-1487$. [CrossRef]

37. le Polain de Waroux, J.B.; Pouleur, A.C.; Goffinet, C.; Pasquet, A.; Vanoverschelde, J.L.; Gerber, B.L. Combined coronary and late-enhanced multidetector-computed tomography for delineation of the etiology of left ventricular dysfunction: Comparison with coronary angiography and contrast-enhanced cardiac magnetic resonance imaging. Eur. Heart J. 2008, 29, $2544-2551$. [CrossRef]

38. Bouleti, C.; Baudry, G.; Iung, B.; Arangalage, D.; Abtan, J.; Ducrocq, G.; Steg, P.-G.; Vahanian, A.; Henry-Feugeas, M.-C.; Pasi, N.; et al. Usefulness of Late Iodine Enhancement on Spectral CT in Acute Myocarditis. JACC Cardiovasc. Imaging 2017, 10, 826-827. [CrossRef]

39. Liguori, C.; Farina, D.; Vaccher, F.; Ferrandino, G.; Bellini, D.; Carbone, I. Myocarditis: Imaging up to date. Radiol. Med. 2020, 125, 1124-1134. [CrossRef]

40. Liu, P.P.; Mason, J.W. Advances in the understanding of myocarditis. Circulation 2001, 104, 1076-1082. [CrossRef]

41. Chetrit, M.; Friedrich, M.G. The unique role of cardiovascular magnetic resonance imaging in acute myocarditis. F1000Resarch 2018, 7, 1153. [CrossRef] [PubMed]

42. Karamitsos, T.D.; Francis, J.M.; Neubauer, S. The current and emerging role of cardiovascular magnetic resonance in the diagnosis of nonischemic cardiomyopathies. Prog. Cardiovasc. Dis. 2011, 54, 253-265. [CrossRef] [PubMed]

43. Huttin, O.; Frikha, Z.; Brembilla-Perrot, B.; Sellal, J.M.; Mandry, D.; Aliot, E.; Juilliere, Y.; Sadoul, N.; Selton-Suty, C. Acute myocarditis presenting with ventricular arrhythmias: The role of CMR in the differential diagnosis of ARVD. Intern. Med. 2013, 52, 1915-1918. [CrossRef] [PubMed]

44. Hofmann, R.; Trappe, H.J.; Klein, H.; Kemnitz, J. Chronic (or healed) myocarditis mimicking arrhythmogenic right ventricular dysplasia. Eur. Heart J. 1993, 14, 717-720. [CrossRef] [PubMed]

45. Monney, P.; Locca, D.; Muzzarelli, S.; Hullin, R.; Jeanrenaud, X.; Schwitter, J. IRM cardiaque: Imagerie de référence dans le diagnostic de la myocardite aiguë? (Cardiac magnetic resonance in acute myocarditis: A new non-invasive diagnostic gold standard?). Rev. Med. Suisse 2012, 8, 1177-1183.

46. Lurz, P.; Eitel, I.; Adam, J.; Steiner, J.; Grothoff, M.; Desch, S.; Fuernau, G.; de Waha, S.; Sareban, M.; Luecke, C.; et al. Diagnostic performance of CMR imaging compared with EMB in patients with suspected myocarditis. JACC Cardiovasc. Imaging 2012, 5, 513-524. [CrossRef]

47. Lewis, A.J.M.; Burrage, M.K.; Ferreira, V.M. Cardiovascular magnetic resonance imaging for inflammatory heart diseases. Cardiovasc. Diagn. Ther. 2020, 10, 598-609. [CrossRef]

48. Ferreira, V.M.; Schulz-Menger, J.; Holmvang, G.; Kramer, C.M.; Carbone, I.; Sechtem, U.; Kindermann, I.; Gutberlet, M.; Cooper, L.T.; Liu, P.; et al. Cardiovascular Magnetic Resonance in Nonischemic Myocardial Inflammation: Expert Recommendations. J. Am. Coll. Cardiol. 2018, 72, 3158-3176. [CrossRef] 
49. Mirakhur, A.; Anca, N.; Mikami, Y.; Merchant, N. T2-weighted imaging of the heart-A pictorial review. Eur. J. Radiol. 2013, 82, 1755-1762. [CrossRef]

50. Guglin, M.; Nallamshetty, L. Myocarditis: Diagnosis and treatment. Curr. Treat. Options Cardiovasc. Med. 2012, 14, 637-651. [CrossRef]

51. Abdel-Aty, H.; Boyé, P.; Zagrosek, A.; Wassmuth, R.; Kumar, A.; Messroghli, D.; Bock, P.; Dietz, R.; Friedrich, M.G.; Schulz-Menger J. Diagnostic performance of cardiovascular magnetic resonance in patients with suspected acute myocarditis: Comparison of different approaches. J. Am. Coll. Cardiol. 2005, 45, 1815-1822. [CrossRef] [PubMed]

52. Ferreira, V.M.; Piechnik, S.K.; Dall'Armellina, E.; Karamitsos, T.D.; Francis, J.M.; Ntusi, N.; Holloway, C.; Choudhury, R.P.; Kardos, A.; Robson, M.D.; et al. T(1) mapping for the diagnosis of acute myocarditis using CMR: Comparison to T2-weighted and late gadolinium enhanced imaging. JACC Cardiovasc. Imaging 2013, 6, 1048-1058. [CrossRef] [PubMed]

53. Abdel-Aty, H.; Cocker, M.; Strohm, O.; Filipchuk, N.; Friedrich, M.G. Abnormalities in T2-weighted cardiovascular magnetic resonance images of hypertrophic cardiomyopathy: Regional distribution and relation to late gadolinium enhancement and severity of hypertrophy. J. Magn. Reson. Imaging 2008, 28, 242-245. [CrossRef]

54. Mahrholdt, H.; Goedecke, C.; Wagner, A.; Meinhardt, G.; Athanasiadis, A.; Vogelsberg, H.; Fritz, P.; Klingel, K.; Kandolf, R.; Sechtem, U. Cardiovascular magnetic resonance assessment of human myocarditis: A comparison to histology and molecular pathology. Circulation 2004, 109, 1250-1258. [CrossRef] [PubMed]

55. Wagner, A.; Mahrholdt, H.; Holly, T.A.; Elliott, M.D.; Regenfus, M.; Parker, M.; Klocke, F.J.; Bonow, R.O.; Kim, R.J.; Judd, R.M. Contrast-enhanced MRI and routine single photon emission computed tomography (SPECT) perfusion imaging for detection of subendocardial myocardial infarcts: An imaging study. Lancet 2003, 361, 374-379. [CrossRef]

56. Verhaert, D.; Thavendiranathan, P.; Giri, S.; Mihai, G.; Rajagopalan, S.; Simonetti, O.P.; Raman, S.V. Direct T2 quantification of myocardial edema in acute ischemic injury. JACC Cardiovasc. Imaging 2011, 4, 269-278. [CrossRef]

57. Giri, S.; Chung, Y.C.; Merchant, A.; Mihai, G.; Rajagopalan, S.; Raman, S.V.; Simonetti, O.P. T2 quantification for improved detection of myocardial edema. J. Cardiovasc. Magn. Reson. 2009, 11, 56. [CrossRef]

58. Messroghli, D.R.; Greiser, A.; Fröhlich, M.; Dietz, R.; Schulz-Menger, J. Optimization and validation of a fully-integrated pulse sequence for modified look-locker inversion-recovery (MOLLI) T1 mapping of the heart. J. Magn. Reson. Imaging 2007, 26, 1081-1086. [CrossRef]

59. Piechnik, S.K.; Ferreira, V.M.; Dall'Armellina, E.; Cochlin, L.E.; Greiser, A.; Neubauer, S.; Robson, M.D. Shortened Modified Look-Locker Inversion recovery (ShMOLLI) for clinical myocardial T1-mapping at 1.5 and 3 T within a 9 heartbeat breathhold. J. Cardiovasc. Magn. Reson. 2010, 12, 69. [CrossRef]

60. Chow, K.; Flewitt, J.A.; Green, J.D.; Pagano, J.J.; Friedrich, M.G.; Thompson, R.B. Saturation recovery single-shot acquisition (SASHA) for myocardial T(1) mapping. Magn. Reson. Med. 2014, 71, 2082-2095. [CrossRef]

61. Roujol, S.; Weingärtner, S.; Foppa, M.; Chow, K.; Kawaji, K.; Ngo, L.H.; Kellman, P.; Manning, W.J.; Thompson, R.B.; Nezafat, R. Accuracy, precision, and reproducibility of four T1 mapping sequences: A head-to-head comparison of MOLLI, ShMOLLI, SASHA, and SAPPHIRE. Radiology 2014, 272, 683-689. [CrossRef] [PubMed]

62. Baeßler, B.; Schaarschmidt, F.; Stehning, C.; Schnackenburg, B.; Maintz, D.; Bunck, A.C. A systematic evaluation of three different cardiac T2-mapping sequences at 1.5 and 3T in healthy volunteers. Eur. J. Radiol. 2015, 84, 2161-2170. [CrossRef] [PubMed]

63. Cau, R.; Bassareo, P.; Saba, L. Cardiac Involvement in COVID-19-Assessment with Echocardiography and Cardiac Magnetic Resonance Imaging. SN Compr. Clin. Med. 2020, 2, 845-851. [CrossRef]

64. Mavrogeni, S.; Apostolou, D.; Argyriou, P.; Velitsista, S.; Papa, L.; Efentakis, S.; Vernardos, E.; Kanoupaki, M.; Kanoupakis, G.; Manginas, A. T1 and T2 Mapping in Cardiology: "Mapping the Obscure Object of Desire". Cardiology 2017, 138, $207-217$. [CrossRef] [PubMed]

65. Huber, A.T.; Bravetti, M.; Lamy, J.; Bacoyannis, T.; Roux, C.; De Cesare, A.; Rigolet, A.; Benveniste, O.; Allenbach, Y.; Kerneis, M.; et al. Non-invasive differentiation of idiopathic inflammatory myopathy with cardiac involvement from acute viral myocarditis using cardiovascular magnetic resonance imaging T1 and T2 mapping. J. Cardiovasc. Magn. Reson. 2018, 20, 11. [CrossRef]

66. Kim, R.J.; Albert, T.S.; Wible, J.H.; Elliott, M.D.; Allen, J.C.; Lee, J.C.; Parker, M.; Napoli, A.; Judd, R.M. Performance of delayedenhancement magnetic resonance imaging with gadoversetamide contrast for the detection and assessment of myocardial infarction: An international, multicenter, double-blinded, randomized trial. Circulation 2008, 117, 629-637. [CrossRef]

67. Messroghli, D.R.; Moon, J.C.; Ferreira, V.M.; Grosse-Wortmann, L.; He, T.; Kellman, P.; Mascherbauer, J.; Nezafat, R.; Salerno, M.; Schelbert, E.B.; et al. Clinical recommendations for cardiovascular magnetic resonance mapping of T1, T2, T2* and extracellular volume: A consensus statement by the Society for Cardiovascular Magnetic Resonance (SCMR) endorsed by the European Association for Cardiovascular Imaging (EACVI). J. Cardiovasc. Magn. Reson. 2017, 19, 75. [CrossRef]

68. Kirkbride, R.R.; Rawal, B.; Mirsadraee, S.; Galperin-Aizenberg, M.; Wechalekar, K.; Ridge, C.A.; Litmanovich, D.E. Imaging of Cardiac Infections: A Comprehensive Review and Investigation Flowchart for Diagnostic Workup. J. Thorac. Imaging 2020, 36, W70-W88. [CrossRef]

69. Baeßler, B.; Treutlein, M.; Schaarschmidt, F.; Stehning, C.; Schnackenburg, B.; Michels, G.; Maintz, D.; Bunck, A.C. A novel multiparametric imaging approach to acute myocarditis using T2-mapping and CMR feature tracking. J. Cardiovasc. Magn. Reson. 2017, 19, 71. [CrossRef] 
70. Luetkens, J.A.; Faron, A.; Isaak, A.; Dabir, D.; Kuetting, D.; Feisst, A.; Schmeel, F.C.; Sprinkart, A.M.; Thomas, D. Comparison of Original and 2018 Lake Louise Criteria for Diagnosis of Acute Myocarditis: Results of a Validation Cohort. Radiol. Cardiothorac. Imaging 2019, 1, 3. [CrossRef]

71. Alexander, C.; Oberhausen, E. Myocardial scintigraphy. Semin. Nucl. Med. 1995, 25, 195-201. [CrossRef]

72. Moralidis, E.; Mantziari, L.; Gerasimou, G.; Styliadis, I.H.; Gotzamani-Psarrakou, A. Somatostatin analogue scintigraphy in a patient with viral myocarditis. Hell. J. Nucl. Med. 2012, 15, 144-146. [CrossRef] [PubMed]

73. O'Connell, J.B.; Henkin, R.E.; Robinson, J.A.; Subramanian, R.; Scanlon, P.J.; Gunnar, R.M. Gallium-67 imaging in patients with dilated cardiomyopathy and biopsy-proven myocarditis. Circulation 1984, 70, 58-62. [CrossRef] [PubMed]

74. Strain, J.E.; Fine, E.; Grose, R.M.; Kramer, D.C.; Cho, S.; Factor, S.M. Comparison of myocardial biopsy and gallium-67 imaging for diagnosing myocarditis. Circulation 1983, 68 (Suppl. 111), 208.

75. Hung, M.Y.; Hung, M.J.; Cheng, C.W. Use of gallium 67 scintigraphy to differentiate acute myocarditis from acute myocardial infarction. Tex. Heart Inst. J. 2007, 34, 305-309.

76. Narula, J.; Khaw, B.A.; Dec, G.W.; Palacios, I.F.; Newell, J.B.; Southern, J.F.; Fallon, J.T.; Strauss, H.W.; Haber, E.; Yasuda, T. Diagnostic accuracy of antimyosin scintigraphy in suspected myocarditis. J. Nucl. Cardiol. 1996, 3, 371-381. [CrossRef]

77. Yasuda, T.; Palacios, I.F.; Dec, G.W.; Fallon, J.T.; Gold, H.K.; Leinbach, R.C.; Strauss, H.W.; Khaw, B.A.; Haber, E. Indium 111-monoclonal antimyosin antibody imaging in the diagnosis of acute myocarditis. Circulation 1987, 76, 306-311. [CrossRef]

78. Le Guludec, D.; Sarda, L.; Rouzet, F.; Merlet, P.; Slama, M.S.; Lebtahi, R. Imaging inflammatory cardiomyopathies. J. Nucl. Cardiol. 2005, 12, 731-739. [CrossRef]

79. Martin, M.E.; Moya-Mur, J.L.; Casanova, M.; Crespo-Diez, A.; Asin-Cardiel, E.; Castro-Beiras, J.M.; Diez-Jimenez, L.; Ballester, M.; Carrio, I.; Narula, J. Role of noninvasive antimyosin imaging in infants and children with clinically suspected myocarditis. J. Nucl. Med. 2004, 45, 429-437.

80. Kühl, U.; Lauer, B.; Souvatzoglu, M.; Vosberg, H.; Schultheiss, H.P. Antimyosin scintigraphy and immunohistologic analysis of endomyocardial biopsy in patients with clinically suspected myocarditis-evidence of myocardial cell damage and inflammation in the absence of histologic signs of myocarditis. J. Am. Coll. Cardiol. 1998, 32, 1371-1376. [CrossRef]

81. Sun, Y.; Ma, P.; Bax, J.J.; Blom, N.; Yu, Y.; Wang, Y.; Han, X.; Wang, Y.; Van Der Wall, E.E. 99mTc-MIBI myocardial perfusion imaging in myocarditis. Nucl. Med. Commun. 2003, 24, 779-783. [CrossRef] [PubMed]

82. Javadi, H.; Jallalat, S.; Pourbehi, G.; Semnani, S.; Mogharrabi, M.; Nabipour, I.; Ravanbod, M.; Amini, A.; Assadi, M. The role of gated myocardial perfusion scintigraphy (GMPS) in myocarditis: A case report and review of the literature. Nucl. Med. Rev. Cent. East. Eur. 2011, 14, 112-115. [CrossRef] [PubMed]

83. Kiratli, P.O.; Tuncel, M.; Ozkutlu, S.; Caglar, M. Gated myocardial perfusion scintigraphy in children with myocarditis: Can it be considered as an indicator of clinical outcome? Nucl. Med. Commun. 2008, 29, 907-914. [CrossRef] [PubMed]

84. Skouri, H.N.; Dec, G.W.; Friedrich, M.G.; Cooper, L.T. Noninvasive imaging in myocarditis. J. Am. Coll. Cardiol. 2006, 48, 2085-2093. [CrossRef] [PubMed]

85. Hoey, E.T.; Gulati, G.S.; Ganeshan, A.; Watkin, R.W.; Simpson, H.; Sharma, S. Cardiovascular MRI for assessment of infectious and inflammatory conditions of the heart. AJR Am. J. Roentgenol. 2011, 197, 103-112. [CrossRef] [PubMed]

86. Boccara, F.; Blanchard-Lemoine, B.; Sarda, L.; Bardet, J.; Le Guludec, D.; Cohen, A. Conduite diagnostique dans les myocardites aiguës (Diagnostic strategy in acute myocarditis). Arch. Mal. CoEur. Vaiss. 1998, 91, 1151-1158. [PubMed]

87. Dec, G.W.; Palacios, I.; Yasuda, T.; Fallon, J.T.; Khaw, B.A.; Strauss, H.W.; Haber, E. Antimyosin antibody cardiac imaging: Its role in the diagnosis of myocarditis. J. Am. Coll. Cardiol. 1990, 16, 97-104. [CrossRef]

88. Yilmaz, A.; Klingel, K.; Kandolf, R.; Sechtem, U. Imaging in inflammatory heart disease: From the past to current clinical practice. Hell. J. Cardiol. 2009, 50, 449-460.

89. Lawal, I.; Sathekge, M. F-18 FDG PET/CT imaging of cardiac and vascular inflammation and infection. Br. Med. Bull. 2016, 120, 55-74. [CrossRef]

90. Chen, W.; Jeudy, J. Assessment of Myocarditis: Cardiac MR, PET/CT, or PET/MR? Curr. Cardiol. Rep. 2019, 21, 76. [CrossRef]

91. Schneider, S.; Batrice, A.; Rischpler, C.; Eiber, M.; Ibrahim, T.; Nekolla, S.G. Utility of multimodal cardiac imaging with PET/MRI in cardiac sarcoidosis: Implications for diagnosis, monitoring and treatment. Eur. Heart J. 2014, 35, 312. [CrossRef] [PubMed]

92. Genovesi, D.; Bauckneht, M.; Altini, C.; Popescu, C.E.; Ferro, P.; Monaco, L.; Borra, A.; Ferrari, C.; Caobelli, F. The role of positron emission tomography in the assessment of cardiac sarcoidosis. Br. J. Radiol. 2019, 92, 20190247. [CrossRef] [PubMed]

93. von Olshausen, G.; Hyafil, F.; Langwieser, N.; Laugwitz, K.L.; Schwaiger, M.; Ibrahim, T. Detection of acute inflammatory myocarditis in Epstein Barr virus infection using hybrid 18F-fluoro-deoxyglucose-positron emission tomography/magnetic resonance imaging. Circulation 2014, 130, 925-926. [CrossRef] [PubMed]

94. Nensa, F.; Poeppel, T.D.; Krings, P.; Schlosser, T. Multiparametric assessment of myocarditis using simultaneous positron emission tomography/magnetic resonance imaging. Eur. Heart J. 2014, 35, 2173. [CrossRef]

95. Prato, F.S.; Butler, J.; Sykes, J.; Keenliside, L.; Blackwood, K.J.; Thompson, R.T.; White, J.A.; Mikami, Y.; Thiessen, J.D.; Wisenberg, G. Can the inflammatory response be evaluated using 18F-FDG within zones of microvascular obstruction after myocardial infarction? J. Nucl. Med. 2015, 56, 299-304. [CrossRef]

96. Lamacie, M.M.; Almufleh, A.; Nair, V.; Stadnick, E.; Birnie, D.; Beanlands, R.; Chih, S. Serial 18F-Fluorodeoxyglucose Positron Emission Tomography Imaging in a Patient With Giant Cell Myocarditis. Circ. Cardiovasc. Imaging 2020, 13, e009940. [CrossRef] 
97. Nensa, F.; Kloth, J.; Tezgah, E.; Poeppel, T.D.; Heusch, P.; Goebel, J.; Nassenstein, K.; Schlosser, T. Feasibility of FDG-PET in myocarditis: Comparison to CMR using integrated PET/MRI. J. Nucl. Cardiol. 2018, 25, 785-794. [CrossRef]

98. FDG-PET/CT Images Comparing to MRI and Endomyocardial Biopsy in Myocarditis (STREAM). ClinicalTrials.gov Identifier: NCT04085718. Available online: https:/ / clinicaltrials.gov/ct2/show/NCT04085718 (accessed on 29 December 2021).

99. Chopra, H.; Arangalage, D.; Bouleti, C.; Zarka, S.; Fayard, F.; Chillon, S.; Laissy, J.P.; Henry-Feugeas, M.C.; Steg, P.G.; Vahanian, A.; et al. Prognostic value of the infarct- and no n-infarct like patterns and cardiovascular magnetic resonance parameters on long-term outcome of patients after acute myocarditis. Int. J. Cardiol. 2016, 212, 63-69. [CrossRef]

100. Mewton, N.; Dernis, A.; Bresson, D.; Zouaghi, O.; Croisille, P.; Flocard, E.; Douek, P.; Bonnefoy-Cudraz, E. Myocardial biomarkers and delayed enhanced cardiac magnetic resonance relationship in clinically suspected myocarditis and insight on clinical outcome. J. Cardiovasc. Med. 2015, 16, 696-703. [CrossRef]

101. Aquaro, G.D.; Perfetti, M.; Camastra, G.; Monti, L.; Dellegrottaglie, S.; Moro, C.; Pepe, A.; Todiere, G.; Lanzillo, C.; Scatteia, A.; et al. Cardiac MR With Late Gadolinium Enhancement in Acute Myocarditis With Preserved Systolic Function: ITAMY Study. J. Am. Coll. Cardiol. 2017, 70, 1977-1987. [CrossRef]

102. World Health Organization. WHO Director-General's Opening Remarks at the Media Briefing on COVID-19-11 March 2020. Available online: https:/ / www.who.int/director-general/speeches/detail/who-director-general-s-opening-remarks-at-themedia-briefing-on-covid-19---11-march-2020 (accessed on 9 December 2021).

103. De Lorenzo, A.; Kasal, D.A.; Tura, B.R.; Lamas, C.C.; Rey, H.C. Acute cardiac injury in patients with COVID-19. Am. J. Cardiovasc. Dis. 2020, 10, 28-33. [PubMed]

104. Atri, D.; Siddiqi, H.K.; Lang, J.P.; Nauffal, V.; Morrow, D.A.; Bohula, E.A. COVID-19 for the Cardiologist: Basic Virology, Epidemiology, Cardiac Manifestations, and Potential Therapeutic Strategies. JACC Basic Transl. Sci. 2020, 5, 518-536. [CrossRef] [PubMed]

105. Purdy, A.; Ido, F.; Sterner, S.; Tesoriero, E.; Matthews, T.; Singh, A. Myocarditis in COVID-19 presenting with cardiogenic shock: A case series. Eur. Heart J. Case Rep. 2021, 5, ytab028. [CrossRef]

106. Zheng, Y.Y.; Ma, Y.T.; Zhang, J.Y.; Xie, X. COVID-19 and the cardiovascular system. Nat. Rev. Cardiol. 2020, 17, 259-260. [CrossRef] [PubMed]

107. Clerkin, K.J.; Fried, J.A.; Raikhelkar, J.; Sayer, G.; Griffin, J.M.; Masoumi, A.; Jain, S.S.; Burkhoff, D.; Kumaraiah, D.; Rabbani, L.; et al. COVID-19 and Cardiovascular Disease. Circulation 2020, 141, 1648-1655. [CrossRef] [PubMed]

108. Pirzada, A.; Mokhtar, A.T.; Moeller, A.D. COVID-19 and Myocarditis: What Do We Know So Far? CJC Open 2020, 2, $278-285$. [CrossRef] [PubMed]

109. Agricola, E.; Beneduce, A.; Esposito, A.; Ingallina, G.; Palumbo, D.; Palmisano, A.; Ancona, F.; Baldetti, L.; Pagnesi, M.; Melisurgo, G.; et al. Heart and Lung Multimodality Imaging in COVID-19. JACC Cardiovasc. Imaging 2020, 13, 1792-1808. [CrossRef]

110. Cameli, M.; Pastore, M.C.; Henein, M.; Aboumarie, H.S.; Mandoli, G.E.; D’Ascenzi, F.; Cameli, P.; Franchi, F.; Mondillo, S.; Valente, S. Safe performance of echocardiography during the COVID-19 pandemic: A practical guide. Rev. Cardiovasc. Med. 2020, 21, 217-223. [CrossRef]

111. Citro, R.; Pontone, G.; Bellino, M.; Silverio, A.; Iuliano, G.; Baggiano, A.; Manka, R.; Iesu, S.; Vecchione, C.; Asch, F.M.; et al. Role of multimodality imaging in evaluation of cardiovascular involvement in COVID-19. Trends Cardiovasc. Med. 2021, 31, 8-16. [CrossRef]

112. The European Society for Cardiology. ESC Guidance for the Diagnosis and Management of CV Disease during the COVID19 Pandemic-Updated. Available online: https://www.escardio.org/Education/COVID-19-and-Cardiology (accessed on 9 December 2021).

113. Zhang, L.; Wang, B.; Zhou, J.; Kirkpatrick, J.; Xie, M.; Johri, A.M. Bedside Focused Cardiac Ultrasound in COVID-19 from the Wuhan Epicenter: The Role of Cardiac Point-of-Care Ultrasound, Limited Transthoracic Echocardiography, and Critical Care Echocardiography. J. Am. Soc. Echocardiogr. 2020, 33, 676-682. [CrossRef]

114. Huang, G.; Vengerovsky, A.; Morris, A.; Town, J.; Carlbom, D.; Kwon, Y. Development of a COVID-19 Point-of-Care Ultrasound Protocol. J. Am. Soc. Echocardiogr. 2020, 33, 903-905. [CrossRef] [PubMed]

115. Picard, M.H.; Weiner, R.B. Echocardiography in the Time of COVID-19. J. Am. Soc. Echocardiogr. 2020, 33, 674-675. [CrossRef] [PubMed]

116. Drake, D.H.; De Bonis, M.; Covella, M.; Agricola, E.; Zangrillo, A.; Zimmerman, K.G.; Cobey, F.C. Echocardiography in Pandemic: Front-Line Perspective, Expanding Role of Ultrasound, and Ethics of Resource Allocation. J. Am. Soc. Echocardiogr. 2020, 33, 683-689. [CrossRef] [PubMed]

117. Krishnamoorthy, P.; Croft, L.B.; Ro, R.; Anastasius, M.; Zhao, W.; Giustino, G.; Argulian, E.; Goldman, M.E.; Sharma, S.K.; Kini, A.; et al. Biventricular strain by speckle tracking echocardiography in COVID-19: Findings and possible prognostic implications. Future Cardiol. 2021, 17, 663-667. [CrossRef] [PubMed]

118. Rathore, S.S.; Rojas, G.A.; Sondhi, M.; Pothuru, S.; Pydi, R.; Kancherla, N.; Singh, R.; Ahmed, N.K.; Shah, J.; Tousif, S.; et al. Myocarditis associated with Covid-19 disease: A systematic review of published case reports and case series. J. Clin. Pract. 2021, 75, e14470. [CrossRef] [PubMed]

119. Li, R.; Wang, H.; Ma, F.; Cui, G.L.; Peng, L.Y.; Li, C.Z.; Zeng, H.S.; Marian, A.J.; Wang, D.W. Widespread myocardial dysfunction in COVID-19 patients detected by myocardial strain imaging using 2-D speckle-tracking echocardiography. Acta Pharmacol. Sin. 2021, 42, 1567-1574. [CrossRef] [PubMed] 
120. Croft, L.B.; Krishnamoorthy, P.; Ro, R.; Anastasius, M.; Zhao, W.; Buckley, S.; Goldman, M.; Argulian, E.; Sharma, S.K.; Kini, A.; et al. Abnormal left ventricular global longitudinal strain by speckle tracking echocardiography in COVID-19 patients. Future Cardiol. 2021, 17, 655-661. [CrossRef]

121. Trogen, B.; Gonzalez, F.J.; Shust, G.F. COVID-19-Associated Myocarditis in an Adolescent. Pediatric Infect. Dis. J. 2020, 39, e204-e205. [CrossRef]

122. Goerlich, E.; Minhas, A.S.; Mukherjee, M.; Sheikh, F.H.; Gilotra, N.A.; Sharma, G.; Michos, E.D.; Hays, A.G. Multimodality Imaging for Cardiac Evaluation in Patients with COVID-19. Curr. Cardiol. Rep. 2021, 23, 44. [CrossRef]

123. Kirkpatrick, J.N.; Mitchell, C.; Taub, C.; Kort, S.; Hung, J.; Swaminathan, M. ASE Statement on Protection of Patients and Echocardiography Service Providers During the 2019 Novel Coronavirus Outbreak: Endorsed by the American College of Cardiology. J. Am. Coll. Cardiol. 2020, 75, 3078-3084. [CrossRef]

124. Gerber, B.L.; Belge, B.; Legros, G.J.; Lim, P.; Poncelet, A.; Pasquet, A.; Gisellu, G.; Coche, E.; Vanoverschelde, J.L. Characterization of acute and chronic myocardial infarcts by multidetector computed tomography: Comparison with contrast-enhanced magnetic resonance. Circulation 2006, 113, 823-833. [CrossRef]

125. Pontone, G.; Baggiano, A.; Conte, E.; Teruzzi, G.; Cosentino, N.; Campodonico, J.; Rabbat, M.G.; Assanelli, E.; Palmisano, A.; Esposito, A.; et al. "Quadruple Rule-Out" With Computed Tomography in a COVID-19 Patient With Equivocal Acute Coronary Syndrome Presentation. JACC Cardiovasc. Imaging 2020, 13, 1854-1856. [CrossRef] [PubMed]

126. Beitzke, D.; Salgado, R.; Francone, M.; Kreitner, K.F.; Natale, L.; Bremerich, J.; Gutberlet, M.; Mousseaux, E.; Nikolaou, K.; Peebles, C.; et al. Cardiac imaging procedures and the COVID-19 pandemic: Recommendations of the European Society of Cardiovascular Radiology (ESCR). Int. J. Cardiovasc. Imaging 2020, 36, 1801-1810. [CrossRef] [PubMed]

127. Ko, S.M.; Hwang, S.H.; Lee, H.J. Role of Cardiac Computed Tomography in the Diagnosis of Left Ventricular Myocardial Diseases J. Cardiovasc. Imaging. 2019, 27, 73-92. [CrossRef]

128. Poon, M.; Leipsic, J.; Kim, M.; Welt, F.; Rose, G. Impact of Cardiovascular Care of COVID-19: Lessons Learned, Current Challenges, and Future Opportunities. Radiol. Cardiothorac. Imaging 2020, 2, e200251. [CrossRef] [PubMed]

129. Dambrin, G.; Laissy, J.P.; Serfaty, J.M.; Caussin, C.; Lancelin, B.; Paul, J.F. Diagnostic value of ECG-gated multidetector computed tomography in the early phase of suspected acute myocarditis. A preliminary comparative study with cardiac MRI. Eur. Radiol. 2007, 17, 331-338. [CrossRef] [PubMed]

130. Esposito, A.; Palmisano, A.; Barbera, M.; Vignale, D.; Benedetti, G.; Spoladore, R.; Ancona, M.B.; Giannini, F.; Oppizzi, M.; Del Maschio, A.; et al. Cardiac Computed Tomography in Troponin-Positive Chest Pain: Sometimes the Answer Lies in the Late Iodine Enhancement or Extracellular Volume Fraction Map. JACC Cardiovasc. Imaging 2019, 12, 745-748. [CrossRef]

131. Rodriguez-Granillo, G.A.; Carrascosa, P.; Cipriano, S.; de Zan, M.; Deviggiano, A.; Capunay, C.; Cury, R.C. Myocardial signal density levels and beam-hardening artifact attenuation using dual-energy computed tomography. Clin. Imaging 2015, 39, 809-814. [CrossRef]

132. Skulstad, H.; Cosyns, B.; Popescu, B.A.; Galderisi, M.; di Salvo, G.; Donal, E.; Petersen, S.; Gimelli, A.; Haugaa, K.H.; Muraru, D.; et al. COVID-19 pandemic and cardiac imaging: EACVI recommendations on precautions, indications, prioritization, and protection for patients and healthcare personnel. Eur. Heart J. Cardiovasc. Imaging 2020, 21, 592-598. [CrossRef]

133. Choi, A.D.; Abbara, S.; Branch, K.R.; Feuchtner, G.M.; Ghoshhajra, B.; Nieman, K.; Pontone, G.; Villines, T.C.; Williams, M.C.; Blankstein, R. Society of Cardiovascular Computed Tomography guidance for use of cardiac computed tomography amidst the COVID-19 pandemic Endorsed by the American College of Cardiology. J. Cardiovasc. Comput. Tomogr. 2020, 14, 101-104. [CrossRef]

134. Sanghvi, S.K.; Schwarzman, L.S.; Nazir, N.T. Cardiac MRI and Myocardial Injury in COVID-19: Diagnosis, Risk Stratification and Prognosis. Diagnostics 2021, 11, 130. [CrossRef] [PubMed]

135. Kotecha, T.; Knight, D.S.; Razvi, Y.; Kumar, K.; Vimalesvaran, K.; Thornton, G.; Patel, R.; Chacko, L.; Brown, J.T.; Coyle, C.; et al. Patterns of myocardial injury in recovered troponin-positive COVID-19 patients assessed by cardiovascular magnetic resonance. Eur. Heart J. 2021, 42, 1866-1878. [CrossRef] [PubMed]

136. Panchal, A.; Kyvernitakis, A.; Mikolich, J.R.; Biederman, R.W.W. Contemporary use of cardiac imaging for COVID-19 patients: A three center experience defining a potential role for cardiac MRI. Int. J. Cardiovasc. Imaging 2021, 37, 1721-1733. [CrossRef]

137. Puntmann, V.O.; Carerj, M.L.; Wieters, I.; Fahim, M.; Arendt, C.; Hoffmann, J.; Shchendrygina, A.; Escher, F.; Vasa-Nicotera, M.; Zeiher, A.M.; et al. Outcomes of Cardiovascular Magnetic Resonance Imaging in Patients Recently Recovered From Coronavirus Disease 2019 (COVID-19). JAMA Cardiol. 2020, 5, 1265-1273. [CrossRef] [PubMed]

138. Rajpal, S.; Tong, M.S.; Borchers, J.; Zareba, K.M.; Obarski, T.P.; Simonetti, O.P.; Daniels, C.J. Cardiovascular Magnetic Resonance Findings in Competitive Athletes Recovering From COVID-19 Infection. JAMA Cardiol. 2021, 6, 116-118. [CrossRef] [PubMed]

139. Daniels, C.J.; Rajpal, S.; Greenshields, J.T.; Rosenthal, G.L.; Chung, E.H.; Terrin, M.; Jeudy, J.; Mattson, S.E.; Law, I.H.; Borchers, J.; et al. Prevalence of Clinical and Subclinical Myocarditis in Competitive Athletes With Recent SARS-CoV-2 Infection: Results From the Big Ten COVID-19 Cardiac Registry. JAMA Cardiol. 2021, 6, 1078-1087. [CrossRef]

140. Wang, H.; Li, R.; Zhou, Z.; Jiang, H.; Yan, Z.; Tao, X.; Li, H.; Xu, L. Cardiac involvement in COVID-19 patients: Mid-term follow up by cardiovascular magnetic resonance. J. Cardiovasc. Magn. Reson. 2021, 23, 14. [CrossRef] [PubMed]

141. Saeed, M.; Van, T.A.; Krug, R.; Hetts, S.W.; Wilson, M.W. Cardiac MR imaging: Current status and future direction. Cardiovasc. Diagn. Ther. 2015, 5, 290-310. [CrossRef] 
142. Kelle, S.; Bucciarelli-Ducci, C.; Judd, R.M.; Kwong, R.Y.; Simonetti, O.; Plein, S.; Raimondi, F.; Weinsaft, J.W.; Wong, T.C.; Carr, J. Society for Cardiovascular Magnetic Resonance (SCMR) recommended CMR protocols for scanning patients with active or convalescent phase COVID-19 infection. J. Cardiovasc. Magn. Reson. 2020, 22, 61. [CrossRef]

143. Skali, H.; Murthy, V.L.; Al-Mallah, M.H.; Bateman, T.M.; Beanlands, R.; Better, N.; Calnon, D.A.; Dilsizian, V.; Gimelli, A.; Pagnanelli, R.; et al. Guidance and Best Practices for Nuclear Cardiology Laboratories During the COVID-19 Pandemic: An Information Statement From ASNC and SNMMI. Circ. Cardiovasc. Imaging 2020, 13, e011761. [CrossRef]

144. Minamimoto, R.; Hotta, M.; Ishikane, M.; Inagaki, T. FDG-PET/CT images of COVID-19: A comprehensive review. Glob. Health Med. 2020, 2, 221-226. [CrossRef] [PubMed]

145. Fields, B.K.K.; Demirjian, N.L.; Dadgar, H.; Gholamrezanezhad, A. Imaging of COVID-19: CT, MRI, and PET. Semin. Nucl. Med. 2020, 51, 312-320. [CrossRef] [PubMed]

146. Alam, S.R.; Shah, A.S.V.; Ombati, K.O.; Nganga, E.; Gitau, S.; Makhdomi, K.; Chung, M.H.; Vinayak, S. CardiOvaScular Mechanisms In Covid-19: Methodology of a prospective observational multimodality imaging study (COSMIC-19 study). BMC Cardiovasc. Disord. 2021, 21, 234. [CrossRef] [PubMed] 